Article

\title{
The Impacts of Climate Variability and Land Use Change on Streamflow in the Hailiutu River Basin
}

\author{
Guangwen Shao, Yiqing Guan, Danrong Zhang *, Baikui Yu and Jie Zhu \\ College of Hydrology and Water Resources, Hohai University, Nanjing 210098, China; \\ guangwenshao@hhu.edu.cn (G.S.); yiqingguan@hhu.edu.cn (Y.G.); yubaikui@126.com (B.Y.); \\ zhujie58603586@163.com (J.Z.) \\ * Correspondence: danrong_zhang@hhu.edu.cn; Tel.: +86-177-6172-4730
}

Received: 6 March 2018; Accepted: 17 June 2018; Published: 20 June 2018

Abstract: The Hailiutu River basin is a typical semi-arid wind sandy grass shoal watershed in northwest China. Climate and land use have changed significantly during the period 1970-2014. These changes are expected to impact hydrological processes in the basin. The Mann-Kendall (MK) test and sequential $t$-test analysis of the regime shift method were used to detect the trend and shifts of the hydrometeorological time series. Based on the analyzed results, seven scenarios were developed by combining different land use and/or climate situations. The Soil Water Assessment Tool (SWAT) model was applied to analyze the impacts of climate variability and land use change on the values of the hydrological components. The China Meteorological Assimilation Driving Datasets for the SWAT model (CMADS) was applied to enhance the spatial expressiveness of precipitation data in the study area during the period 2008-2014. Rather than solely using observed precipitation or CMADS precipitation, the precipitation values of CMADS and the observed precipitation values were combined to drive the SWAT model for better simulation results. From the trend analysis, the annual streamflow and wind speed showed a significant downward trend. No significant trend was found for the annual precipitation series; however, the temperature series showed upward trends. With the change point analysis, the whole study period was divided into three sub-periods (1970-1985, 1986-2000, and 2001-2014). The annual precipitation, mean wind speed, and average temperature values were $316 \mathrm{~mm}, 2.62 \mathrm{~m} / \mathrm{s}$, and $7.9^{\circ} \mathrm{C}$, respectively, for the sub-period 1970-1985, $272 \mathrm{~mm}, 2.58 \mathrm{~m} / \mathrm{s}$, and $8.4^{\circ} \mathrm{C}$, respectively, for the sub-period 1986-2000, and $391 \mathrm{~mm}, 2.2 \mathrm{~m} / \mathrm{s}$, and $9.35{ }^{\circ} \mathrm{C}$, respectively, for the sub-period 2001-2014. The simulated mean annual streamflow was $35.09 \mathrm{~mm} /$ year during the period 1970-1985. Considering the impact of the climate variability, the simulated mean annual streamflow values were $32.94 \mathrm{~mm} /$ year (1986-2000) and $36.78 \mathrm{~mm}$ /year (2001-2014). Compared to the period 1970-1985, the simulated mean annual streamflow reduced by $2.15 \mathrm{~mm}$ /year for the period 1986-2000 and increased by $1.69 \mathrm{~mm}$ /year for the period 2001-2014. The main variations of land use from 1970 to 2014 were the increased area of shrub and grass land and decreased area of sandy land. In the simulation it was shown that these changes caused the mean annual streamflow to decrease by $0.23 \mathrm{~mm} /$ year and $0.68 \mathrm{~mm} /$ year during the periods 1986-2000 and 2001-2014, respectively. Thus, the impact of climate variability on the streamflow was more profound than that of land use change. Under the impact of coupled climate variability and land use change, the mean annual streamflow decreased by $2.45 \mathrm{~mm} /$ year during the period 1986-2000, and the contribution of this variation to the decrease in observed streamflow was $27.8 \%$. For the period 2001-2014, the combined climate variability and land use change resulted in an increase of $0.84 \mathrm{~mm} /$ year in annual streamflow. The results obtained in this study could provide guidance for water resource management and planning in the Erdos plateau.

Keywords: statistical analysis; SWAT; CMADS; climate variability; land use change; streamflow 


\section{Introduction}

Climate variability and land use change are recognized as two important factors influencing hydrological processes. Studies showed that the increased temperature could result in corresponding changes in the timing and volume of spring flood and evapotranspiration [1,2]. The variability of precipitation, especially the changes in frequency and intensity of extreme precipitation events, could lead to a variation in stream flow and peak flow. Land use changes are directly linked to changes in the hydrological processes, such as evapotranspiration, interception, and infiltration, etc., and then to the impact of groundwater recharge, baseflow, and streamflow, etc. [3-6].

In general, the methods of assessing the impacts of climate variability/land use change on hydrological processes can be mainly divided into three groups, which are time series analysis, paired catchments experiments, and hydrological modeling [7]. Time series analysis is easy to implement as it is a statistical method [8-10]. However, it can only be applied to simple analysis of the hydrological effects of climate variability/land use change, and lacks physical mechanisms. Paired catchments experiments and hydrological modeling can be applied to research into the interaction between hydrological and climate variability/land use change [11]. The advantage of paired catchments experiment is that it can remove climate variability/land use change through the comparison of two catchments under the similar climatic conditions/land use [12]. Nevertheless, this approach is difficult to apply to larger basins and is very time consuming [13]. In recent years, hydrological models have often been applied to study the relationship between climate variability/land use change and hydrological processes, for the inhomogeneity of climate and land use can be introduced to these models [3,14-16].

Among the widely used hydrological models, the Soil Water Assessment Tool (SWAT) is a utility model, as it has the capability for simulating many processes such as the hydrologic cycle, sediment transportation, and soil erosion. In the SWAT model, with GIS (Geographic Information System) and other interface tools, information on topographic, land use, and soil data can be conveniently written to input parameters of the model. Because SWAT is an open-source model, researchers can conveniently improve the simulation performance in specific study areas. Meanwhile, the SWAT model can be easily calibrated and incorporate changes in land use [17]. As a result, it is a widely used tool for the study of the hydrological effects of environmental change [18-20]. Yin [21] applied the SWAT model to quantify the impact of climate variability/land use change on the streamflow over a long historical time period. Kim [22] used SWAT model to evaluate the separated and combined impacts of future changes and land use changes on the streamflow. Commonly, researchers analyze the trend and change points of historical hydro-meteorology data before building the SWAT model $[13,23]$. The former can help to understand the effects of climate variability on streamflow and the latter can help to select a period with no significant human activity in order to build the SWAT model [23].

Precipitation is an important input variable in the SWAT model. The accuracy of hydrological simulation could be directly affected by the quantity and quality of precipitation data. Regular and sufficient rain gauges can aid in revealing the exact spatial distribution of precipitation. However, in some areas there are fewer rain gauges and it may difficult to exactly reflect the spatial distribution of precipitation $[24,25]$. Combining satellite data and observed data to estimate rainfall is an effective method to solve the problem. Based on this method, several products have been developed and widely applied in hydrological modeling [26,27]. The China Meteorological Assimilation Driving Datasets for the SWAT model (CMADS), which was developed by Dr. Xianyong Meng from the China Institute of Water Resources and Hydropower Research (IWHR), is one such product and has been widely applied in numerous studies [28-31]. For example, Liu [28] found that CMADS had unique advantages in hydrological simulations compared with observed data and Climate Forecast System Reanalysis (CFSR). Zhao [30], based on CMADS, applied three methods to analyze the parameter uncertainty in a mountain-loess transitional watershed. Cao [31] applied CMADS to estimate hydrological elements in the Lijiang River basin. 
The Hailiutu River basin, which belongs to the middle Yellow River basin, is a typical sandy grass shoal watershed in the Erdos plateau in northwest China. This basin has undergone climate variability and land use change in recent decades [32]. Studies showed that in the central-south Yellow River basin the intensity of precipitation extremes increased between the years 1986 and 2011, and may have resulted in increased surface runoff $[33,34]$. The annual average air temperature showed a significant increasing trend in recent decades which may induce the occurrence of increased evapotranspiration $[13,35]$. Studies also showed that streamflow change is more sensitive to precipitation than temperature in the Yellow River basin, especially in the middle section [36,37]. Because of the implementation of the desert greening policy, the land use of study area has changed, i.e., increasing the area of shrub and grass land and decreasing the area of sand land [32]. The increased shrub and grass land could result in decreased baseflow and increased surface runoff and evapotranspiration [6,15]. Meanwhile, the water demand has increased in recent decades, especially after the Erdos Plateau was targeted as a priority area of the western development strategy for China in the 21st century. Accordingly, groundwater extraction, construction of reservoirs, and diversion of dams have increased [38-40]. The streamflow in the Hailiutu River basin is mainly recharged by groundwater, especially in the dry season. More extraction of groundwater would result in decreased streamflow [41,42]. Engineering measures such as reservoir construction and diversion of dams may affect high flow by reducing overland flow and peak streamflow [43]. The annual streamflow of Huangfuchuan basin, which is located in the same climate zone of Hailiutu River basin, has decreased significantly because the increased of construction of check dams [10,44,45]. Therefore, it is necessary to study the impacts of climate variability/land use change and other factors such as the increase of ground water extraction, and construction of reservoirs and diversion dams on the streamflow in the Hailiutu River basin.

The overall objective of this study is to assess the impacts of climate variability and land use change on hydrological components in the Hailiutu River basin in the Erdos plateau. The specific objectives are: (1) to analyze the temporal variation of hydrometeor-ology with trend analysis and change points testing; (2) to evaluate the performance of SWAT model for simulation of streamflow in the Hailiutu River basin; (3) to compare the impact of climate variability on hydrological components with land use change; and (4) to evaluate the effects of climate variability/land use change and other factors, such as the increase of ground water extraction and construction of reservoirs and diversion dams, on streamflow. The results obtained in this study could provide guidance for water resource management and planning in the Erdos plateau.

\section{Materials and Methods}

\subsection{Study Area}

The Hailiutu River is located in the Erdos Plateau in northwest China, and is a tributary of the Wuding River of the Yellow River basin. The Hailiutu River basin $\left(38^{\circ} 02^{\prime}-38^{\circ} 50^{\prime}, 108^{\circ} 37^{\prime}-109^{\circ} 14^{\prime}\right)$ is near the Maowusu desert and covers an area of $2473 \mathrm{~km}^{2}$ (Figure 1). It has a relatively flat topography and the main landscape is of undulating sand dunes [19]. The elevation of the Hailiutu River basin ranges from $1471 \mathrm{~m}$ in the north west region to $1016 \mathrm{~m}$ at the watershed outlet. The geological formation in the Hailiutu River basin can be divided into four strata: (1) the Holocene Aeolian sand with a thickness of 0 to $50 \mathrm{~m}$; (2) the upper Pleistocene Shalawusu sandstone formation of the Quaternary age with a thickness of 5 to $90 \mathrm{~m}$; (3) the Luohe sandstone of Cretaceous age with a thickness of 180 to $330 \mathrm{~m}$, overlain with the Shalawusu formation; and (4) the bedrock, which consists of impermeable Jurassic sediments [39,46-48]. The study area has a semi-arid climate with unevenly distributed precipitation. The mean annual precipitation is $330 \mathrm{~mm}$, with about $80 \%$ of the annual rainfall occurring during the rainy season (June to September). Yang et al. [39,49] found that hydrological processes were mainly affected by direct infiltration and evapotranspiration in the study area. The Hailiutu River has a 
relatively steady discharge even in the dry season (October to May) with groundwater being the primary source of streamflow [32].

\subsection{Data Collection}

The geographic data (topography, soil and land use) and hydrometeorological data are used in this study (Table 1). A $30 \times 30 \mathrm{~m}$ resolution of digital elevation model (DEM) was accessed from the Geospatial Data Cloud of China to calculate the slope (Figure 2a). The soil data, with $1 \times 1 \mathrm{~km}$ resolution, was obtained from the Harmonized Word Soil Database (HWSD) supplied by the Environmental and Ecological Science Data Center for West China. The spatial distribution of soil types is shown in the Figure 2b. Cambic Arenosols represent the most widely distributed soil type, consisting of $89 \%$ sand, $5 \%$ clay, and $6 \%$ silt, and account for $43 \%$ of all soil types in the Hailiutu River basin. Data for land use types with spatial and temporal variation in 1986, 1995, and 2010 were provided by the Data Center for Resources and Environmental Sciences of the Chinese Academy of Sciences (RESDC) (Figure 3). There are six main land use types, including agricultural land, shrub and grass land, forest land, water body, urban land, and sandy land in the Hailiutu River basin. The daily meteorological data from 1970 to 2014, which include wind speed, minimum and maximum temperature, and relative humidity, were acquired from the China Meteorological Sharing Service System. The observed daily rainfall and streamflow data of Hailiutu River basin were provided by the Yellow River Conservancy Commission.

Table 1. Summarized information on the data used for this study. CMADS: China Meteorological Assimilation Driving Datasets for the Soil Water Assessment Tool model.

\begin{tabular}{ccc}
\hline Data Layer & Description of Data Layer & Data Sources \\
\hline Topographic & $\begin{array}{c}30 \times 30 \text { m resolution digital } \\
\text { elevation model (DEM) applied to } \\
\text { calculate slopes and slope lengths }\end{array}$ & Geospatial Data Cloud of China \\
\hline Soil map/layer & $\begin{array}{c}1 \times 1 \mathrm{~km} \text { resolution map; soil layer } \\
\text { attributes for each soil layer }\end{array}$ & $\begin{array}{c}\text { Environmental and Ecological Science } \\
\text { Data Center for West China }\end{array}$ \\
\hline Land use & $30 \times 30$ m resolution map of 1986, 1995, \\
and 2010 & $\begin{array}{c}\text { Data Center for Resources and } \\
\text { Environmental Sciences, Chinese } \\
\text { Academy of Sciences }\end{array}$ \\
\hline Daily meteorological data & $\begin{array}{c}\text { Daily wind speed, minimum } \\
\text { and maximum temperature and relative } \\
\text { humidity from 1970 to 2014 }\end{array}$ & $\begin{array}{c}\text { China Meteorological Sharing } \\
\text { Service System. }\end{array}$ \\
\hline $\begin{array}{c}\text { Daily rainfall and } \\
\text { monthly streamflow }\end{array}$ & $\begin{array}{c}\text { Daily precipitation in/around } \\
\text { watershed monthly streamflow for the } \\
\text { outlet of watershed }\end{array}$ & $\begin{array}{c}\text { Yellow River } \\
\text { Conservancy Commission }\end{array}$ \\
\hline CMADS V1.0 & $\begin{array}{c}\text { Assimilation driving datasets applied to } \\
\text { better reflect the spatial distribution of } \\
\text { precipitation and meteorology }\end{array}$ & http:/ /www.cmads.org \\
\hline
\end{tabular}

There are four rainfall stations and two meteorology stations in the Hailiutu River basin, of which only three rainfall stations are located in the study area. In order to better reflect the spatial distribution of precipitation, the China Meteorological Assimilation Driving Datasets for the SWAT model version 1.0 (CMADS V1.0) was introduced in this study [50]. The CMADS was developed by Dr. Xianyong Meng from the China Institute of Water Resources and Hydropower Research (IWHR) and has received worldwide attention [28-30]. In the CMADS, the integration of air temperature, air pressure, humidity, and wind velocity data were mainly achieved through the LAPS (Local Analysis and Prediction System)/STMAS (Space-Time Multiscale Analysis System). The data sources for the CMADS series include nearly 40,000 regional automatic stations and China's 2421 national automatic and business assessment centers [51-54]. This ensures that the CMADS has wide applicability within the country, and that data accuracy is vastly improved. The CMADS has been widely applied in hydrological simulations and produced better results in China [53,55]. Climate data from the CMADS can be downloaded from the official CMADS website (http:/ / www.cmads.org). 


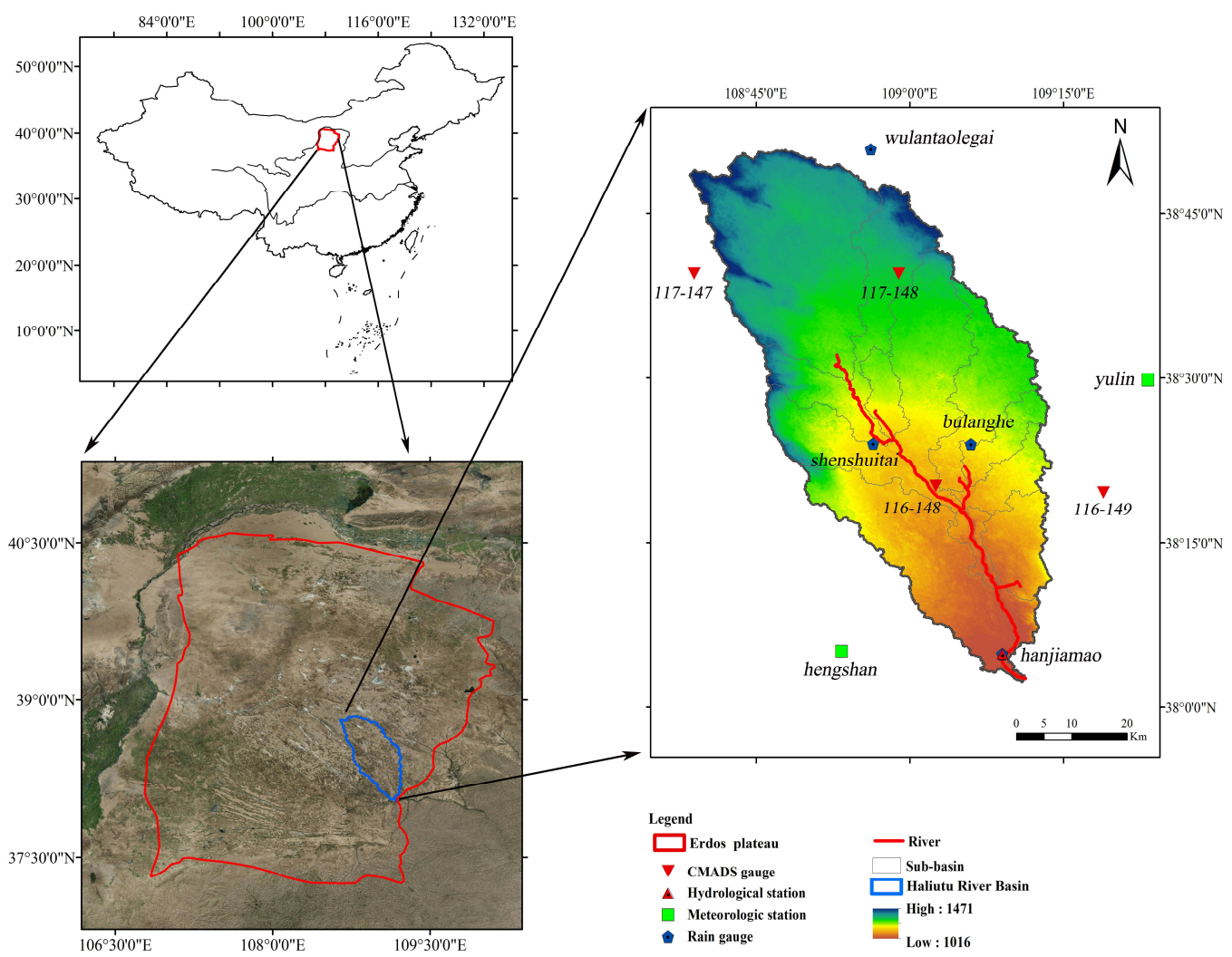

Figure 1. The location of the Hailiutu River basin and its digital elevation model with hydrometeorological stations.

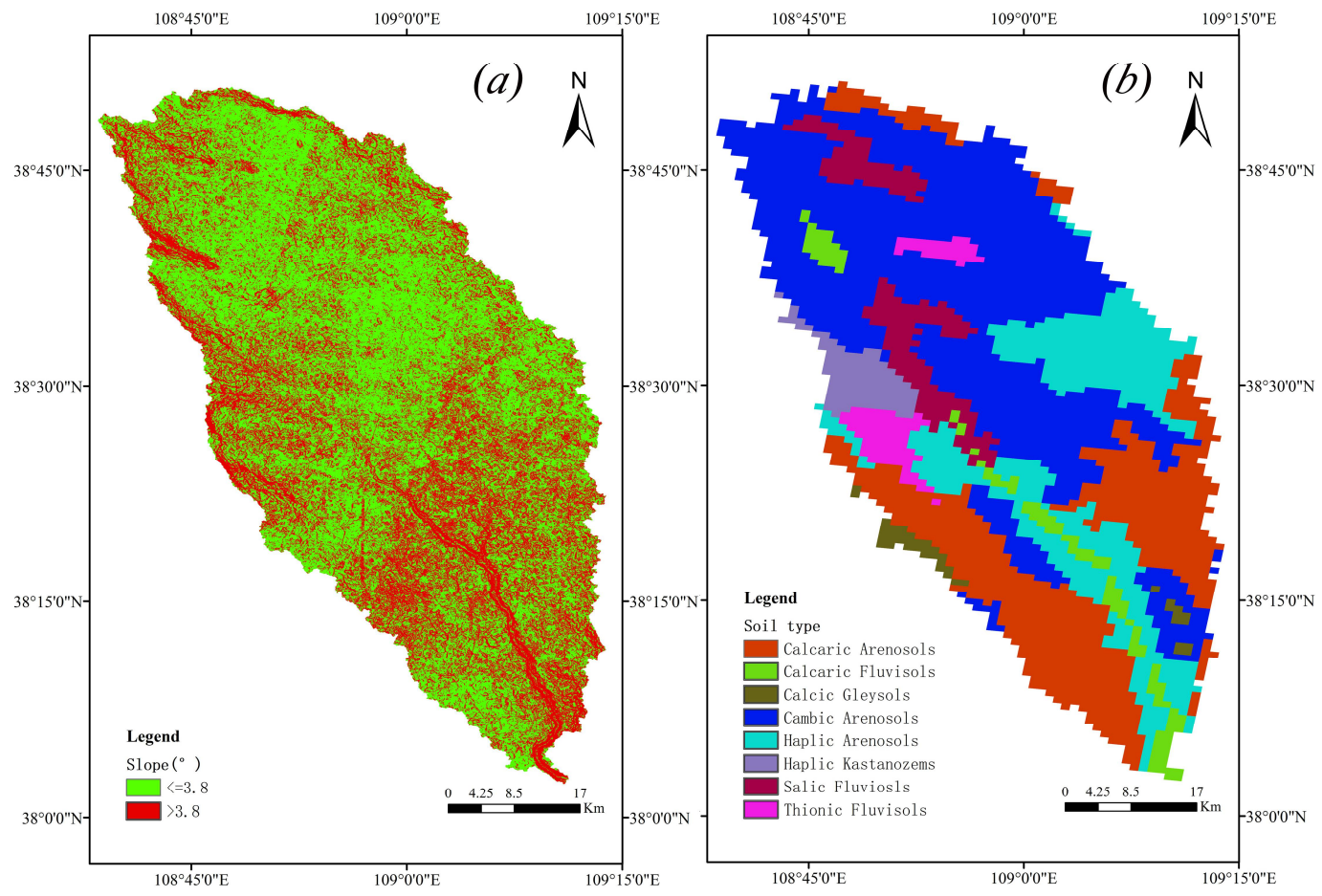

Figure 2. The (a) slope classes and (b) soil types of the Hailiutu River basin. 


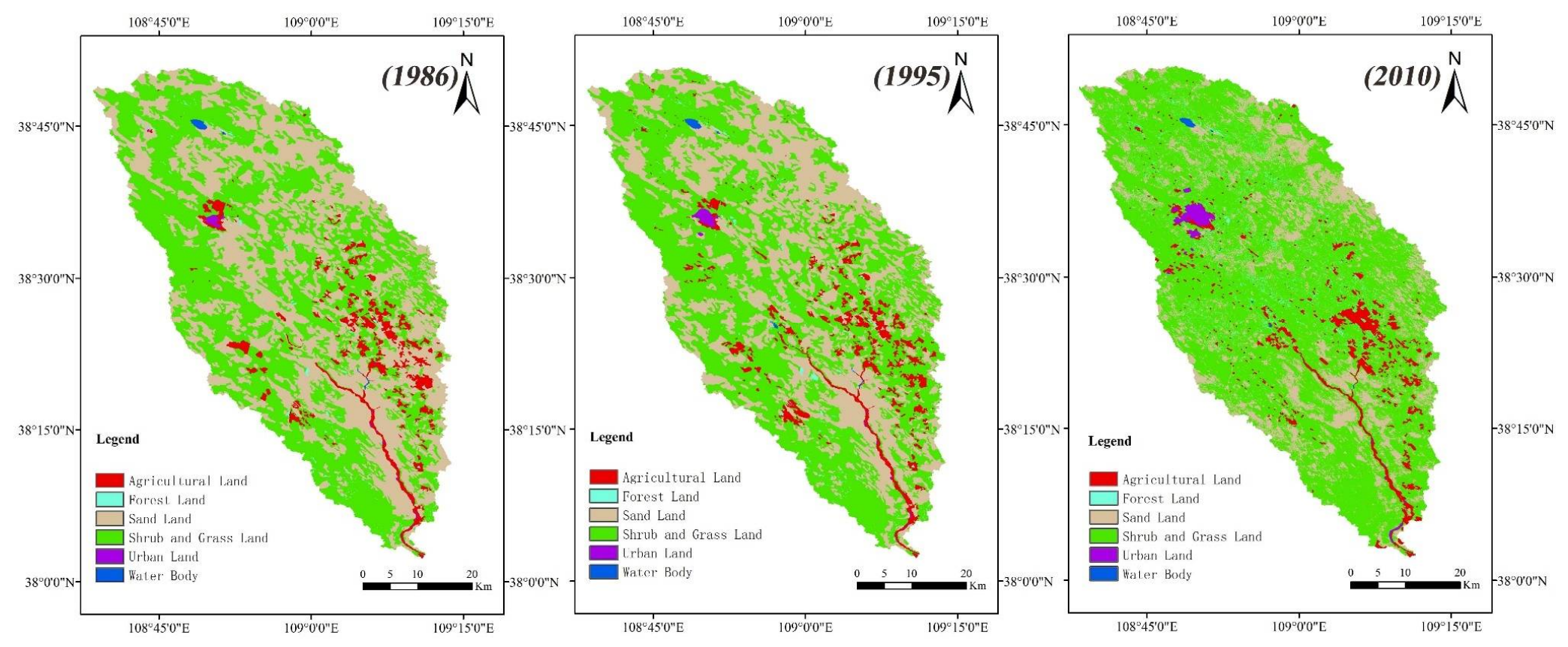

Figure 3. The land use patterns of the Hailiutu River basin for the years 1986, 1995, and 2010. 


\subsection{Methods}

\subsubsection{Time Series Analysis}

\section{Trend Analysis}

The non-parameter Mann-Kendall (MK) test has been widely applied to identify the monotonic tendency and significance in hydro-meteorological time series such as those of precipitation, streamflow, and temperature $[45,56,57]$. The MK test statistic $S$ is calculated as:

$$
S=\sum_{i=1}^{n-1} \sum_{k=i+1}^{n} \operatorname{sgn}\left(x_{k}-x_{i}\right)
$$

where, $x_{k}$ and $x_{i}$ are the sequential data values, $n$ is the length of time series, and the function $\operatorname{sgn}(\theta)$ is defined as:

$$
\operatorname{sgn}(\theta)= \begin{cases}1 & \text { if } \theta>0 \\ 0 & \text { if } \theta=0 \\ -1 & \text { if } \theta<0\end{cases}
$$

For an independent data sample without tied values, the test statistic $S$ is approximate normal distribution, and the variance of $S$ can be calculated by Equation (3).

$$
\operatorname{Var}(S)=\frac{[n(n-1)(2 n+5)]}{18}
$$

Then, the MK test statistic $Z$ can be estimated by Equation (4), where $n$ is larger than 10 .

$$
Z=\left\{\begin{array}{lll}
\frac{S-1}{\sqrt{\operatorname{Var}(S)}} & \text { if } & S>0 \\
0 & \text { if } & S=0 \\
\frac{S+1}{\sqrt{\operatorname{Var}(S)}} & \text { if } & S<0
\end{array}\right.
$$

In the two-sided test, the level of significance was assumed as $\alpha$, and the critical value was defined as $Z_{\alpha / 2}$. Therefore, the null hypothesis $H_{0}$ should be accepted if $|Z| \leq Z_{\alpha / 2}$. The time series has an upward tendency for $Z>0$ and there is a downward tendency for $Z<0$.

\section{Change Point Detection Method}

There are numerous methods to identify the change points of time series, such as Pettitt test, the Mann-Kendall test, sliding $t$ detection, etc. These methods commonly adopt confirmatory statistical techniques with a priori hypothesis to detect the change points of time series. That means substantial amounts of data (at least 10 or more time-series points) should be accumulated to apply a formal statistical test. Therefore, the change points are usually detected long after they actually occurred [58]. In contrast, the sequential $t$-test analysis of regime shift (STARS) method proposed by Rodionov belongs to the category of exploratory or data-driven analysis and does not need an a priori hypothesis that abrupt change has occurred at a certain time [59]. Consequently, the STARS method can detect the change point relatively early when a regime shift occurs $[44,60]$. In this study, the STARS method is used to detect the regime shift of hydrometeorological data.

\subsubsection{Assessing the Impacts of Climate Variability and Land Use Change}

In this study, based on the change point analysis, the hydrometeorology data were divided into three sub-periods (see Section 3.1). Three land use patterns were collected as described in the data collection section during each sub-period. For simplicity, two sub-periods (the prior phase and the latter phase) are displayed in this section (Figure 4). Firstly, the land use and climate condition 
of the prior phase, as the original scenario, was used to calibrate and validate the SWAT model. Subsequently, the changed climate/land use (latter phase) were applied to develop scenarios. Then, based on the calibrated model, the simulation results of each scenario were applied to evaluate the impact of climate variability / land use change on hydrological components. For instance, the impact of land use change on the hydrological components can be evaluated solely by replacing the prior land use pattern with the latter land use pattern. The combined impact of climate variability and land use change on the streamflow also can be assessed by using climate and land use data of the latter phase to drive the calibrated model.

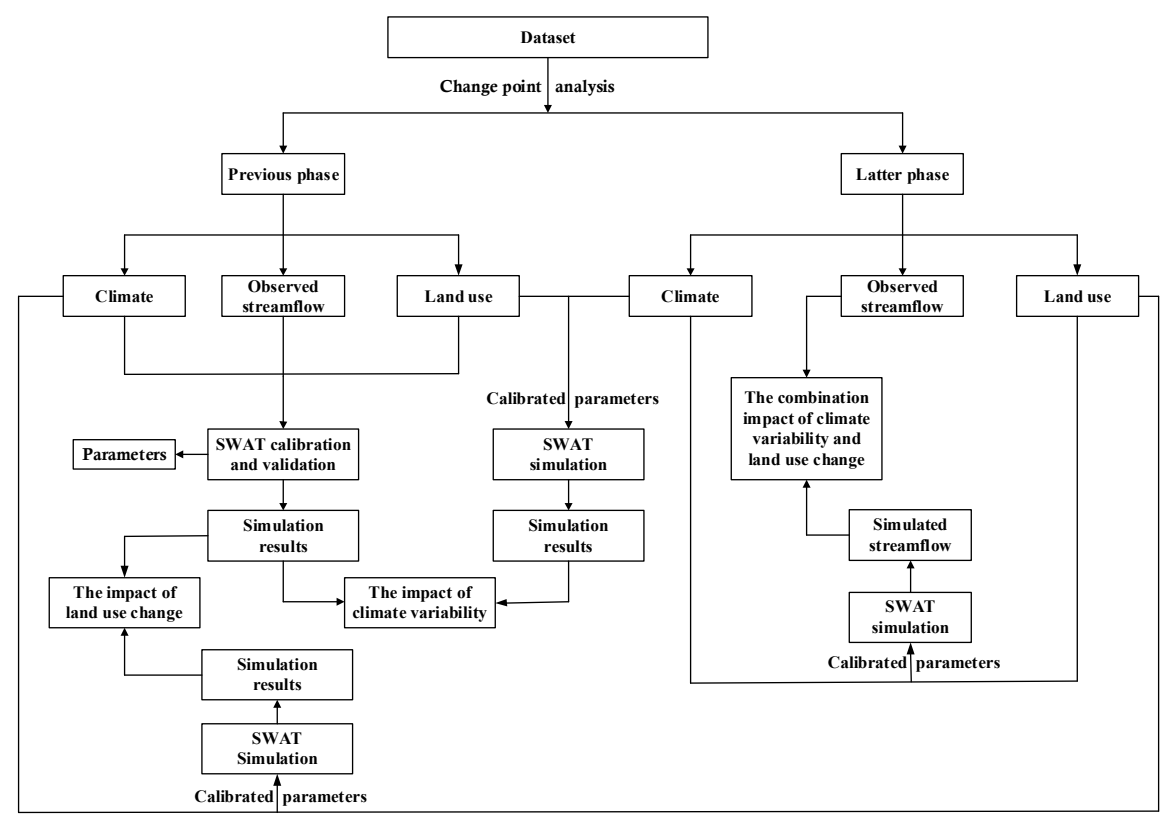

Figure 4. The flowchart for assessing the impacts of climate variability and land use change (refer to Yin et al. [21]). SWAT: Soil Water Assessment Tool.

\subsubsection{SWAT Model and Setup}

The Soil Water Assessment Tool (SWAT) is a comprehensive semi-distributed ecohydrological model that was developed by the United States Department of Agricultural Research Service to simulate the water cycle, transportation of agricultural chemicals, and sediment. In the SWAT model, Hydrological Response Units (HRUs) represent the minimum unit of calculation. Based on the daily components of the hydrological cycle, a daily water budget in each HRU is calculated [61].The main hydrological components of SWAT include surface flow, lateral flow, groundwater flow, percolation, evapotranspiration and transmission losses [6]. In this study, the surface flow is estimated by the modification of the SCS (Soil Conservation Service) curve number procedure method. The lateral flow is estimated by percolation using a kinematic storage model. The groundwater flow is estimated by the linear-reservoir model method. The Penman-Monteith method is applied to calculate potential evapotranspiration (PET) and then the actual evapotranspiration is estimated by PET. Further descriptions of the SWAT model can be found in theoretical documents [61].

Despite its widespread application, the performance of SWAT model varies significantly. Therefore, some researchers have modified the SWAT model to meet their specific requirements. Panagopoulos et al. [62] applied a greatly refined sub watershed structure based on 12-digit hydrological units to improve simulating performance for large-scale watershed. Qi [63] modified the SWAT with an energy balance module to improve the simulation accuracy for snowmelt. In the SWAT model, two forms of groundwater storage (shallow and deep) are applied, of which only the shallow storage is active to simulate the groundwater flow. Researchers found that SWAT 
has poor performance in dry seasons or in areas where groundwater system is complicated and groundwater is the main source of streamflow [64-66]. Therefore, using more active groundwater storage to simulate the groundwater flow could result in a more realistic representation of hydrological cycle in these special cases. According to geological characteristics of the Hailiutu River basin, three active types of groundwater storage (upper, medium, and lower groundwater storage) and one inactive type of groundwater storage (i.e., deep groundwater storage) are introduced in the original SWAT model code of the groundwater module to simulate groundwater flow in the SWAT model (hereafter SWAT means modified SWAT).

In the SWAT model, there are several steps to set up the model. First, based on the DEM, the watershed is delineated and divided into several sub-basins. Then, the sub-basins were further subdivided into HRUs of homogeneous characteristics by the overlaying of slope (calculated from the DEM), land use, and soil layers. Lastly, the information on the DEM, land use, and soil was written into the parameters of the SWAT model. In the watershed delineation and subdivision processes, the actual river system is applied to force the generated streams of the SWAT model to follow the actual stream. In this study, the whole study area was divided into 10 sub-basins based on the actual river system and DEM data (Figure 1). Based on the spatial distribution of land use type (1986), soil type, and slope, the sub-basins were further subdivided into 146 HRUs.

\subsubsection{SWAT Model Calibration and Evaluation}

The sequential uncertainty fitting (SUFI-2) method was applied to calibrate the parameters of SWAT model [67]. The SUFI-2 method combines optimization and uncertainty analysis to adopt a global search procedure. Through Latin hypercube sampling, this method can deal with numerous parameters. In this paper, the Nash-Sutcliffe efficiency (NSE), the determination coefficient $\left(R^{2}\right)$, and percent bias (PBIAS) were employed to evaluate model performance.

For model evaluation, the dataset of the period 1970-1985 was divided into the calibration period (1970-1980) and the validation period (1981-1985). A warm up period from 1970-1974 was chosen to achieve a steady state for modeling. The SWAT model was calibrated by the SUFI-2 method; the calibrated parameters, the best simulated streamflow, and the performance of the SWAT model are presented in Table 2, Figure 5, and Table 3, respectively. For model prediction, it could be found that the 95PPU, i.e., $95 \%$ prediction uncertainty, contained $93 \%$ and $80 \%$ of the observations during the calibration and validation periods, respectively. For monthly streamflow simulation, the model performance can be identified as satisfactory if $0.70<\mathrm{NSE}<0.80,0.75<\mathrm{R}^{2}<0.85$, and $\pm 5<$ PBIAS $< \pm 10$ [68]. Based on 95PPU and criterion values of best simulation, the SWAT model can satisfactorily simulate the monthly streamflow in the Hailiutu River basin.

Table 2. The initial and calibrated parameters selected for the SWAT model for the period 1970-1980.

\begin{tabular}{lcccc}
\hline Parameter & Description & Initial Range & Calibrated Range & Best Value \\
\hline v_alpha_bf_u & Recession factor for upper aquifer & 0.3 to 0.8 & 0.406 to 0.412 & 0.408 \\
v_gw_delay_u & Delay factor for upper aquifer & 1 to 10 & 1.075 to 1.084 & 1.081 \\
v_alpha_bf_m & Recession factor for middle aquifer & 0.005 to 0.1 & 0.069 to 0.076 & 0.07 \\
v_gw_delay_m & Delay factor for middle aquifer & 30 to 350 & 248 to 295 & 283 \\
v_alpha_bf_l & Recession factor for lower aquifer & 0.001 to 0.05 & 0.033 to 0.036 & 0.035 \\
v_gw_delay_l & Delay factor for lower aquifer & 250 to 500 & 452 to 458 & 452 \\
v_rchdp_mld & Percolation factor from upper aquifer & 0.92 to 1 & 0.967 to 0.971 & 0.969 \\
v_rchrg_ld & Percolation factor from middle aquifer & 0.6 to 0.95 & 0.935 to 0.946 & 0.937 \\
v_rchrg_d & Percolation factor from lower aquifer & 0.1 to 0.4 & 0.296 to 0.368 & 0.347 \\
v_gw_revap & Revap & 0.02 to 0.2 & 0.063 to 0.066 & 0.064 \\
r_CN2 & SCS curve number for soil condition II & -0.5 to 0.5 & -0.135 to -0.12 & -0.129 \\
v_esco & Soil evaporation fraction & 0.1 to 0.8 & 0.55 to 0.58 & 0.564 \\
a_awc & Available water capacity of soil layer & -0.04 to 0.1 & -0.04 to -0.036 & -0.038 \\
r_sol_k & Saturated hydraulic conductivity & -0.9 to 0.1 & -0.677 to -0.664 & -0.676 \\
\hline
\end{tabular}

Note: $r$ means to multiply by original value, a means to add or subtract original value and $\mathrm{v}$ means to replace original value. 


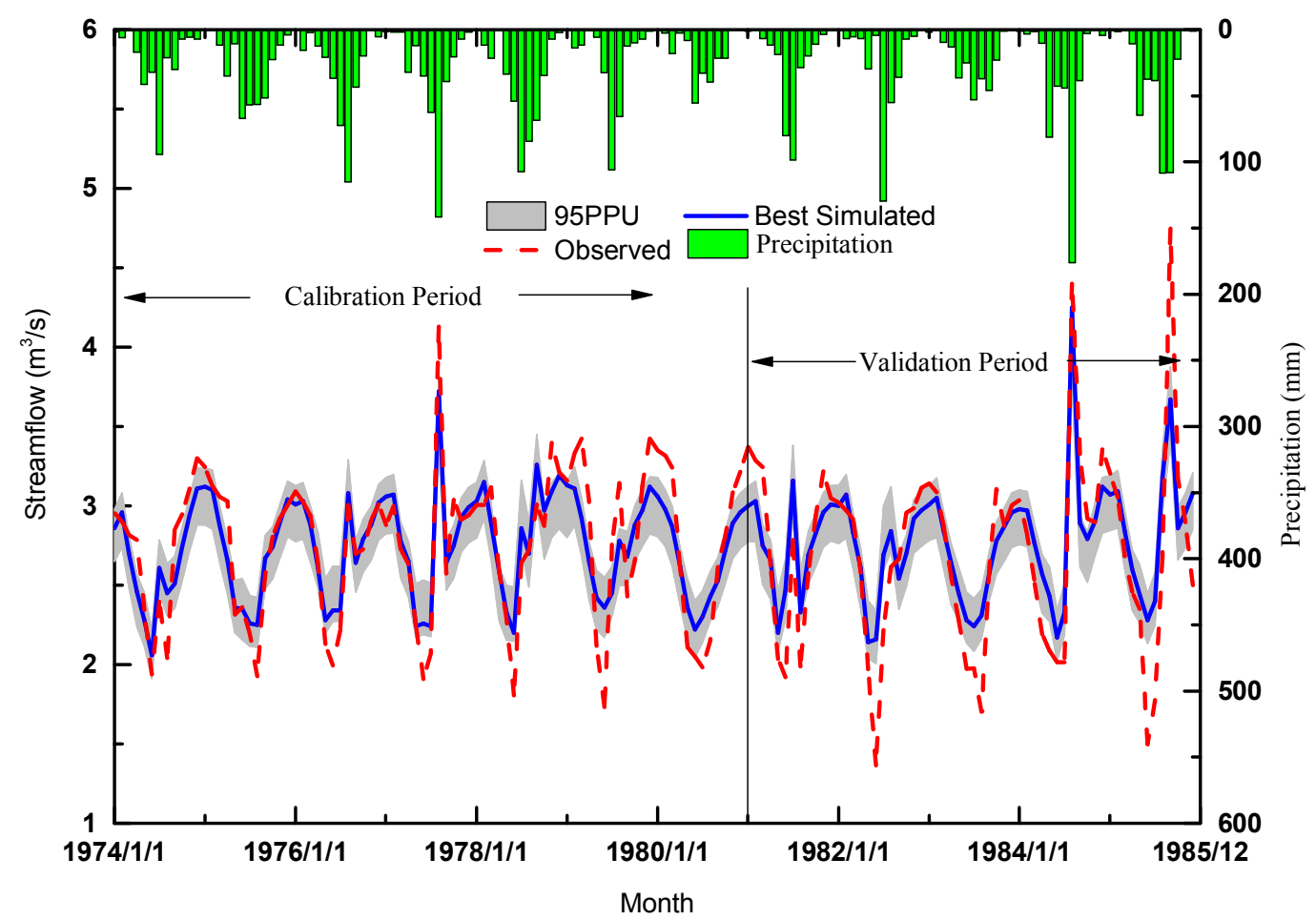

Figure 5. Observed and simulated monthly streamflow of the Hailiutu River basin.

Table 3. The performance of the SWAT model during the calibration and validation periods.

\begin{tabular}{lcccccc}
\hline Criterion & Periods & p-Factor & r-Factor & NSE & $\mathbf{R}^{2}$ & PBIAS \\
\cline { 1 - 5 } Calibration period & 0.93 & 0.76 & 0.78 & 0.80 & -0.43 \\
Validation period & 0.8 & 0.59 & 0.70 & 0.79 & -0.30 \\
\hline
\end{tabular}

\section{Results and Discussion}

\subsection{The Hydrometeorology Analysis for Annual Time Series}

The MK method was applied to analyze trend of hydrometeorology which included annual streamflow, annual precipitation, annual win speed, annual maximum temperature, annual minimum temperature, and annual average temperature in the Hailiutu River basin (Table 4). The test statistic $Z$ value of annual streamflow is -3.69 and its absolute value is larger than the 2.58 . This means the annual streamflow showed a significant downward trend at the 0.01 level of significance during the period 1970-2014. The test statistic $Z$ values of annual precipitation is 1.41 , which is lower than the critical value of 1.64 at the 0.1 level of significance. Therefore, the annual precipitation presented an insignificant upward trend during the study period. The test statistic $Z$ value of the wind speed is -5.57 and its absolute value is larger than 2.58. This means the annual wind speed showed a significant downward trend at the 0.01 level of significance during the period 1970-2014. The test statistic $Z$ values of annual maximum temperature, annual minimum temperature and annual average temperature are positive and larger than 1.96 . Therefore, all temperature series show a significantly upward trend at the 0.05 level of significance. The variation of annual minimum temperature $(Z=5.13)$ is the most pronounced of the three temperature variables. 
Table 4. Results of temporal trends in annual streamflow, precipitation, wind speed, maximum temperature, minimum temperature and mean temperature of the Hailiutu River basin.

\begin{tabular}{|c|c|c|c|c|c|c|}
\hline & \multirow{2}{*}{ Test Statistic Z } & \multicolumn{3}{|c|}{ Threshold of Different Confidence Levels } & \multirow{2}{*}{ Tendency } & \multirow{2}{*}{ Significant } \\
\hline & & 0.01 & 0.05 & 0.1 & & \\
\hline Annual streamflow & -3.69 & 2.58 & 1.96 & 1.64 & Downward & $* * *$ \\
\hline Annual precipitation & 1.41 & 2.58 & 1.96 & 1.64 & Upward & - \\
\hline Annual wind speed & -5.57 & 2.58 & 1.96 & 1.64 & Downward & $* * *$ \\
\hline $\begin{array}{l}\text { Annual maximum } \\
\text { temperature }\end{array}$ & 2.52 & 2.58 & 1.96 & 1.64 & Upward & $* *$ \\
\hline $\begin{array}{l}\text { Annual minimum } \\
\text { temperature }\end{array}$ & 5.13 & 2.58 & 1.96 & 1.64 & Upward & $* * *$ \\
\hline $\begin{array}{l}\text { Annual average } \\
\text { temperature }\end{array}$ & 4.50 & 2.58 & 1.96 & 1.64 & Upward & $* * *$ \\
\hline
\end{tabular}

Note: ${ }^{* *}$ and ${ }^{* * *}$ mean through confidence test under 0.05 and 0.01 level of significance respectively.

The STARS method was used to detect the change points for hydrometeorology during the period 1970-2014 and the results are presented in the Figure 6. As shown in Figure 6, 1986 and 2001 were detected as change points for the annual streamflow. The mean annual streamflow from 1970 to 1985 is $2.73 \mathrm{~m}^{3} / \mathrm{s}$, a value that then sharply decreases to $2.03 \mathrm{~m}^{3} / \mathrm{s}$ during the period $1986-2000$, and finally increases to $2.41 \mathrm{~m}^{3} / \mathrm{s}$ during the 21st century. No significant change point was detected for the annual precipitation, the mean of which was $326 \mathrm{~mm}$ for the whole study period. The years 1979 and 1998 were detected as change points for the annual wind speed. Before the year 1979, mean annual wind speed was $2.71 \mathrm{~m} / \mathrm{s}$, which then decreased to $2.59 \mathrm{~m} / \mathrm{s}$ and $2.2 \mathrm{~m} / \mathrm{s}$ during the periods 1980-1998 and 1999-2014, respectively. For three temperature series, two change points (1999 and 2005) were detected in the annual maximum temperature and only one change point (1999) was detected in the annual average temperature. Before the year 1999 , mean annual maximum temperature was $15.48^{\circ} \mathrm{C}$, which then rose to $16.97^{\circ} \mathrm{C}$ during the period 1999-2004, and finally fell to $15.78^{\circ} \mathrm{C}$ from 2005 to 2014 . Figure $6 \mathrm{e}, \mathrm{f}$ show that annual minimum temperature and average temperature increased abruptly after the year 1999. The mean annual minimum temperature increased from $1.76{ }^{\circ} \mathrm{C}$ (before 1999) to $3.64{ }^{\circ} \mathrm{C}$ (after 1999) while the mean annual average temperature increased from $8.15^{\circ} \mathrm{C}$ (before 1999) to $9.46^{\circ} \mathrm{C}$ (after 1999).

According to the above change points detection results, the data were divided into three sub-periods (1970-1985(C0), 1986-2000 (C1), and 2001-2014 (C2)) by two change points (1986 and 2001). The land use patterns of 1986, 1995, and 2010 were chosen to represent the land use variation for the three sub-periods. In order to analyze the impacts of climate variability and land use change in the Hailiutu River basin, seven scenarios were developed based on the combination of different sub-periods and land use patterns (Table 5). For example, the scenario S0 reflected the climate condition during period C0 and the land use pattern of the year 1986. The scenarios S1 and S2, based on the climate condition during period $\mathrm{C} 1$ and $\mathrm{C} 2$, respectively, were developed to reflect the climate variability with the same land use pattern of S0. The scenarios S0, S5, and S6 can be considered as the actual conditions during the periods $\mathrm{C} 0, \mathrm{C} 1$, and $\mathrm{C} 2$. S0 was applied to the SWAT model as a baseline scenario. The comparison among the simulated results of S0, S1, and S2 revealed the impacts of climate variability on the values of hydrological components. The comparison among the simulated results of S0, S3, and S4 revealed the impacts of land use change on the values of hydrological components. The comparison among the simulated results of S0, S5, and S6 revealed the impacts of the combination of climate variability and land use change on the streamflow.

Table 5. Different scenarios for SWAT modeling.

\begin{tabular}{lcccc}
\hline \hline Sub-Periods & 1970-1985 (C) & 1986-2000 (C1) & 2001-2014 (C2) \\
\cline { 1 - 3 } Land Use Patterns & S0 & S1 & S2 \\
1986 & S3 & S5 & S6 \\
2010 & S4 & & 20 \\
\hline
\end{tabular}



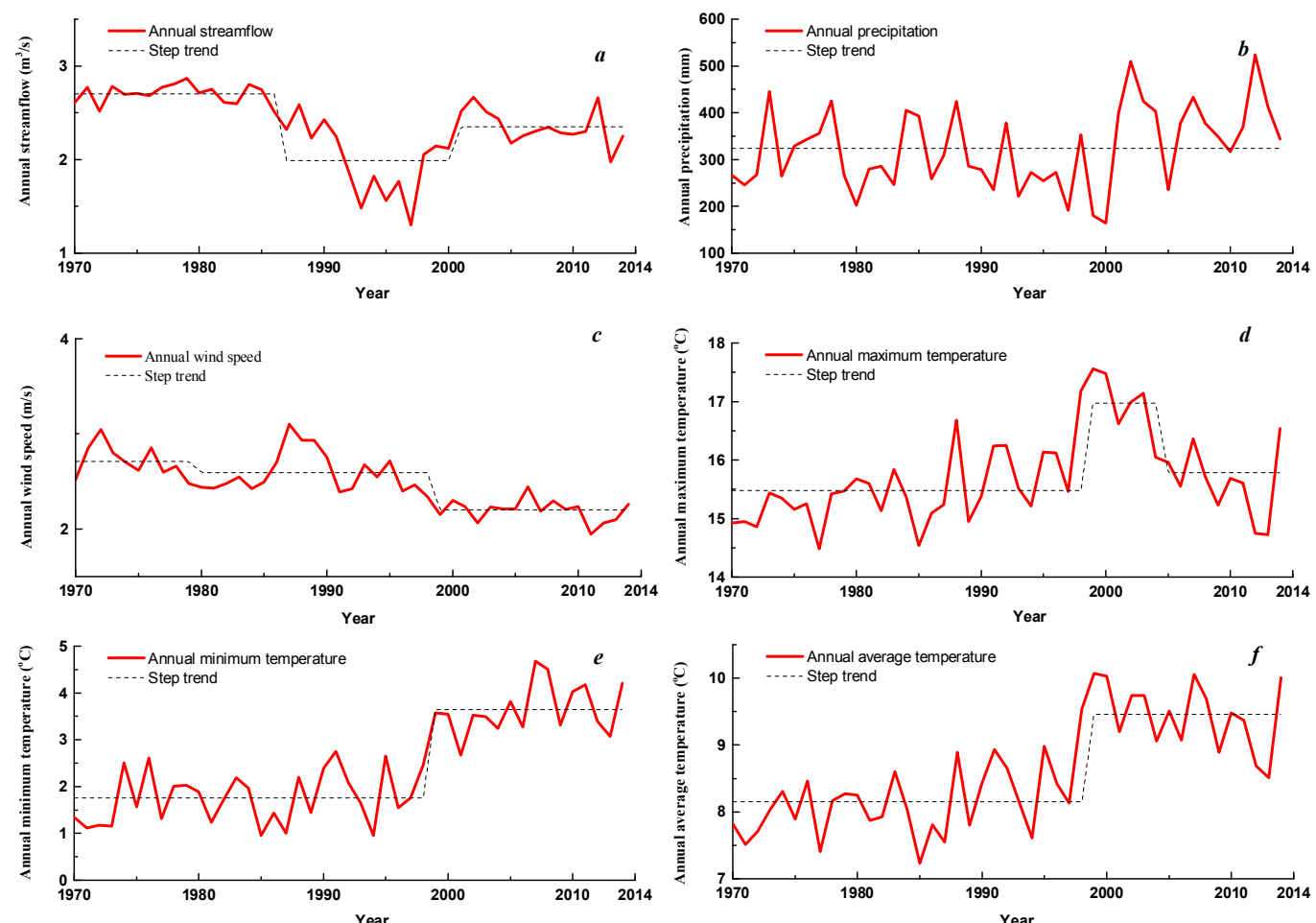

Figure 6. The (a) temporal variation of annual streamflow; (b) precipitation; (c) wind speed; (d) maximum temperature; (e) minimum temperature; and (f) average temperature of the Hailiutu River basin. The dashed lines are the step trends.

\subsection{The Hydrometeorology Analysis for Montly Time Series}

\subsubsection{The Variation of Climate}

The variation of mean monthly streamflow and climate was analyzed during three periods $(C 0, C 1$, and C2) and the results are shown in Figure 7. The streamflow during periods $\mathrm{C} 1$ and $\mathrm{C} 2$ decreased as compared with $\mathrm{C} 0$, in accordance with Figure 6. Compared with $\mathrm{C} 0$, the streamflow during the period C1 decreased in all months, especially in September and October with a streamflow value of $1 \mathrm{~m}^{3} / \mathrm{s}$. The mean monthly streamflow during period $\mathrm{C} 2$ has almost no change compared with $\mathrm{C} 1$ in rainy season, i.e., May to September. However, it increased in other seasons, especially from December to February, raising to similar values as $\mathrm{C} 0$. Compared with $\mathrm{C} 0$, the precipitation decreased substantially during the period $\mathrm{C} 1$. There was no apparent variation in precipitation between $\mathrm{C} 0$ and $\mathrm{C} 2$. Compared with $\mathrm{C} 0$, the mean wind speed during period $\mathrm{C} 1$ showed a decreasing trend from November to May, while it decreased in all months during period C2. In recent decades, the maximum temperature presents upward trend from February to June, especially with respect to the maximum temperature during period $\mathrm{C} 2$ which rose about $3{ }^{\circ} \mathrm{C}$ as compared with $\mathrm{C} 0$. However, in September and December, the maximum temperature during period $\mathrm{C} 2$ decreased compared with $\mathrm{C} 1$, although it had a higher value compared to $\mathrm{C} 0$. The minimum temperature values increased in all months during $\mathrm{C} 1$ and $\mathrm{C} 2$ compared with $\mathrm{C} 0$, and the variation in February was more obvious. 

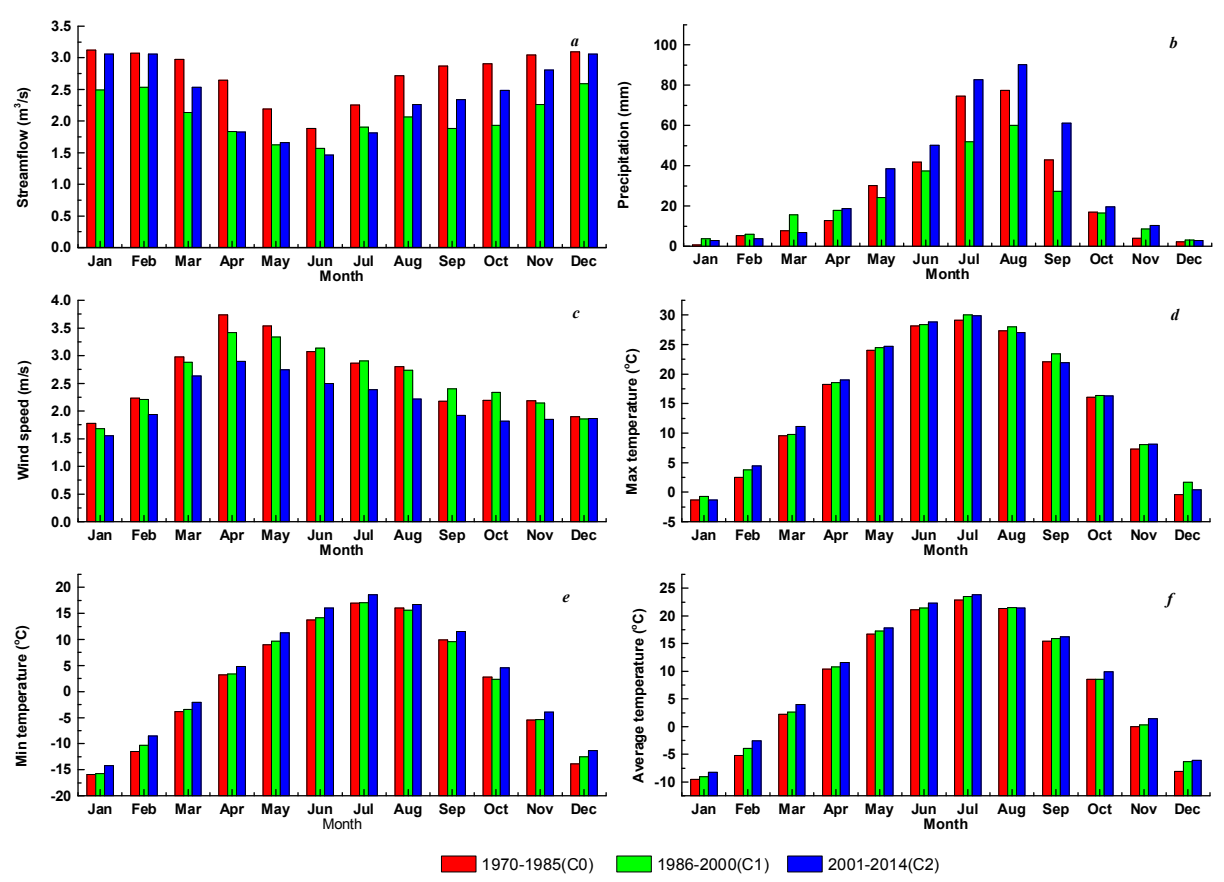

Figure 7. Change variation of (a) mean monthly streamflow; (b) precipitation; (c) wind speed; (d) maximum temperature; (e) minimum temperature; and (f) average temperature of the Hailiutu River basin.

\subsubsection{The Variation of Land Use}

Figure 8 displays the land use change of the study area from 1986 to 2010. As shown in the Figure 8, the main land use types of the year 1986 were: sandy land (43.31\%), shrub and grass land $(51.10 \%)$, and agricultural land $(4.79 \%)$ in the Hailiutu River basin. The predominant three land use types vastly changed during the whole period. The area of shrub and grass land presented a prominent upward trend. This area covered $1797 \mathrm{~km}^{2}$ in 2010 and increased $533.5 \mathrm{~km}^{2}$ or $42.23 \%$ compared with 1986. On the contrary, the sandy land area shows a significant downward trend. This area measured $481.6 \mathrm{~km}^{2}$ in 2010 , a decrease of $589.2 \mathrm{~km}^{2}$ or $55.02 \%$ compared with 1986 . The amount of agricultural land area slightly increased in the 1995, then fell to a similar value as in 1986 in 2010. The area of forest land and urban land account for less than 3\% of the Hailiutu River basin, and both of them showed an apparent upward trend over the past 3 decades. Compared with 1986, the increment in forest land area and urban land area was of $39.8 \mathrm{~km}^{2}$ and $14.4 \mathrm{~km}^{2}$, respectively. At the beginning of the 1980s, an afforestation project named "Three North Forest Shelterbelts" was started by the Chinese government. At the beginning of the 2000s, the local government implemented the policy of "Closing Sandy Land and Forbidding Herding" [32]. The increment of shrub and grass land and the decrement of sandy land can be explained by the implementation of the project and policy.

The transition matrix is commonly applied to analyze the variation in each land use category compared to the other categories. The transition matrix of land use changes in the Hailiutu River basin from 1986 to 2010 is displayed in the Table 6. The columns represent the land use categories in 1986 and the rows represent the categories in 2010. In the third row of Table 6, the values are 55, 0.5, 41.6, $0.1,0.7,22.3$, and 120.2 . That means $55 \mathrm{~km}^{2}$ (marked in bold) of agricultural land was maintained as agricultural land in 2010; $0.5 \mathrm{~km}^{2}$ of forest land changed to agricultural land in 2010; $41.6 \mathrm{~km}^{2}$ of shrub and grass land changed to agricultural land in $2010 ; 0.1 \mathrm{~km}^{2}$ of water changed to agricultural land in $2010 ; 0.7 \mathrm{~km}^{2}$ of urban land changed to agricultural land in 2010; $22.3 \mathrm{~km}^{2}$ of sandy land changed to agricultural land in 2010; and the area of agricultural land was $120.2 \mathrm{~km}^{2}$ in 2010. In the third column of Table 6, the values are 55, 3.6, 53.4, 0.1, 4.7, 1.7, and 118.5. That means $55 \mathrm{~km}^{2}$ of agricultural land was maintained as agricultural land in $2010 ; 3.6 \mathrm{~km}^{2}$ of agricultural land changed to forest land in 2010; 
$53.4 \mathrm{~km}^{2}$ of agricultural land changed to shrub and grass land in 2010; $0.1 \mathrm{~km}^{2}$ of agricultural land changed to water bodies; $4.7 \mathrm{~km}^{2}$ of agricultural land changed to urban land; $1.7 \mathrm{~km}^{2}$ of agricultural land changed to sandy land; and the area of agricultural land was $118.75 \mathrm{~km}^{2}$ in 1986 .

In the Hailiutu River basin, $53.4 \mathrm{~km}^{2}$ of agricultural land converted into shrub and grass land, while $41.6 \mathrm{~km}^{2}$ of shrub and grass land converted to agricultural land. In total, $644.6 \mathrm{~km}^{2}$ of sandy land converted to shrub and grass land, while only $95.1 \mathrm{~km}^{2}$ of shrub and grass land converted to sandy land. This shows that the project and policy of greening the desert achieved remarkable results. Overall, the apparent transformation of land use types is related to sandy land and shrub and grass land, which indicates that the phenomenon of land degradation and desertification still exists in the Hailiutu River basin.

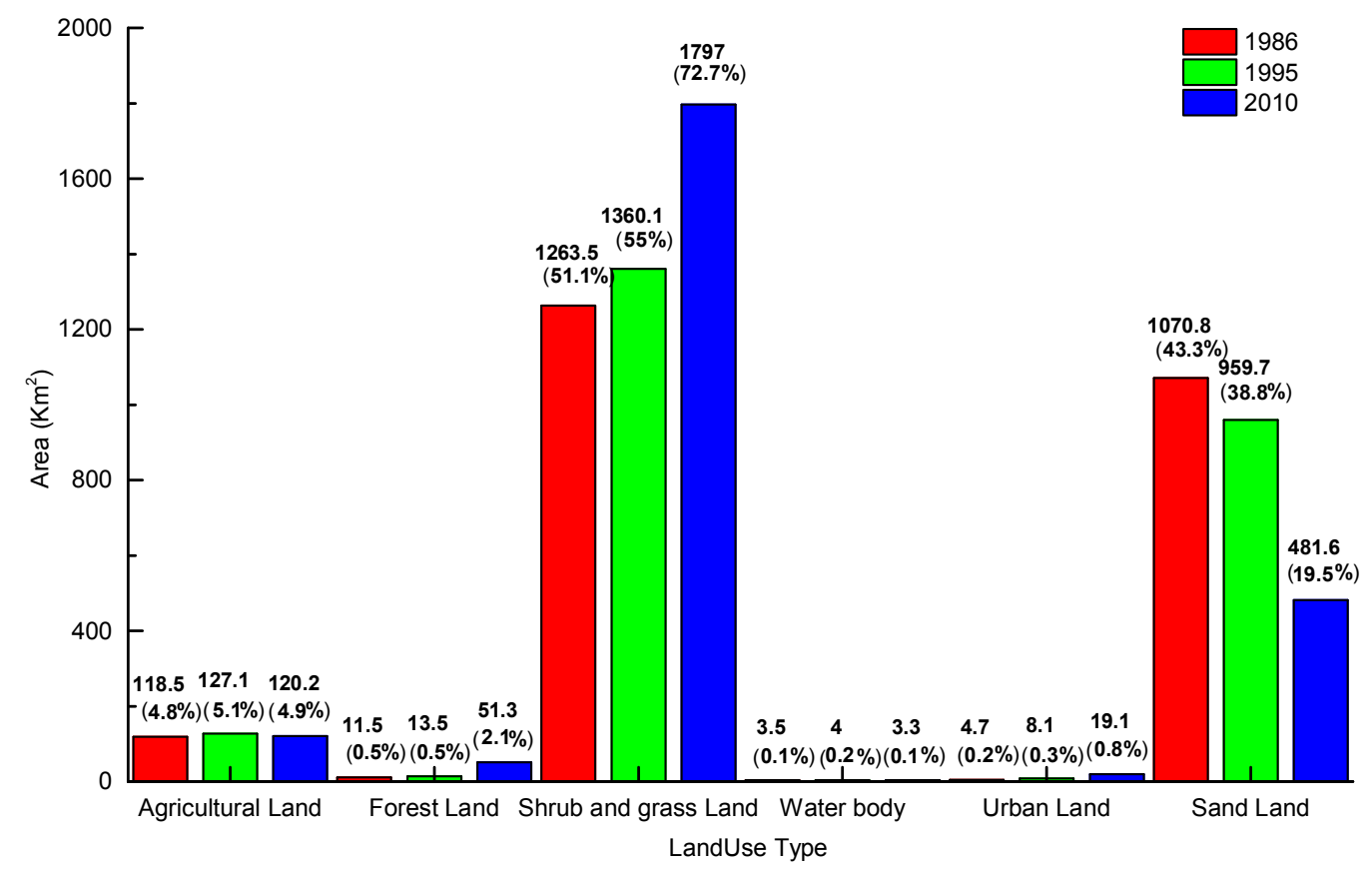

Figure 8. The variation of land used in the three eras. The values in the brackets are the percentages for each type of land use.

Table 6. Transition matrix of land use changes in Hailiutu River basin over the different periods.

\begin{tabular}{|c|c|c|c|c|c|c|c|c|}
\hline & & $\begin{array}{l}\text { Agricultural } \\
\text { Land }\end{array}$ & $\begin{array}{c}\text { Forest } \\
\text { Land }\end{array}$ & $\begin{array}{l}\text { Shrub and Grass } \\
\text { Land }\end{array}$ & $\begin{array}{l}\text { Water } \\
\text { Body }\end{array}$ & $\begin{array}{l}\text { Urban } \\
\text { Land }\end{array}$ & $\begin{array}{l}\text { Sand } \\
\text { Land }\end{array}$ & Total \\
\hline & & \multicolumn{7}{|c|}{1986} \\
\hline \multirow{7}{*}{2010} & Agricultural land & 55 & 0.5 & 41.6 & 0.1 & 0.7 & 22.3 & 120.2 \\
\hline & Forest land & 3.6 & 4 & 26.2 & 0.1 & 0 & 17.4 & 51.3 \\
\hline & Shrub and grass land & 53.4 & 6.5 & 1091.2 & 0.9 & 0.4 & 644.6 & 1797 \\
\hline & Water body & 0.1 & 0 & 0.2 & 2.2 & 0 & 0.8 & 3.3 \\
\hline & Urban land & 4.7 & 0 & 9.2 & 0 & 3.6 & 1.6 & 19.1 \\
\hline & Sand land & 1.7 & 0.5 & 95.1 & 0.2 & 0 & 384.1 & 481.6 \\
\hline & Total & 118.5 & 11.5 & 1263.5 & 3.5 & 4.7 & 1070.8 & \\
\hline
\end{tabular}

Note: The unchanged area of each land use category is marked in bold.

\subsection{The Impacts of Climate Variability on the Value of Hydrological Components}

Table 7 lists the mean annual hydrological components simulated by the SWAT model under different climate variability scenarios. The hydrological components include surface flow, lateral flow, baseflow, and evapotranspiration. All simulated hydrological components under S1 decreased as compared with S0. From the perspective of quantity, the largest decrement occurs in the evapotranspiration ( $-12.3 \mathrm{~mm} /$ year), followed by baseflow $(-2.13 \mathrm{~mm} /$ year). However, from the 
perspective of proportion, an apparent variation occurs in the lateral flow $(-34.5 \%)$, followed by surface flow $(-25.00 \%)$. For S2, all hydrological components increased as compared with S0 except for the baseflow. The simulated surface flow under S2 from the perspective of proportion substantially increased. Also, the simulated evapotranspiration in S2 had a marginal increase as compared with S0 (246.83 vs. $292.36 \mathrm{~mm} /$ year).

Under the impact of climate variability, the simulated mean annual streamflow values during the periods C1 and C2 are $29.73 \mathrm{~mm} /$ year and $38.76 \mathrm{~mm} /$ year, respectively (Table 8). Compared with the period 1970-1985, the variation in mean annual streamflow for the two periods is of $-2.15 \mathrm{~mm}$ /year and $1.69 \mathrm{~mm} /$ year, respectively. That means the climate variability resulted in a decrease of mean annual streamflow by $6.13 \%$ and an increase of mean annual streamflow by $4.82 \%$ during the periods $\mathrm{C} 1$ and $\mathrm{C} 2$, respectively.

Table 7. Changes in annual mean hydrological components under different climate variability scenarios (mm/year).

\begin{tabular}{cccccc}
\hline & S0 & S1 & S2 & S1-S0 & S2-S0 \\
\hline Surface flow & 0.07 & 0.05 & 0.52 & $-0.02(-25.00 \%)$ & $0.45(642.85 \%)$ \\
Lateral flow & 1.37 & 1.07 & 1.71 & $-0.3(-34.50 \%)$ & $0.34(24.82 \%)$ \\
Baseflow & 38.16 & 36.03 & 38.08 & $-2.13(-12.42 \%)$ & $-0.087(-0.21 \%)$ \\
Evapotranspiration & 246.83 & 234.53 & 292.36 & $-12.3(-19.89 \%)$ & $45.53(18.45 \%)$ \\
\hline
\end{tabular}

Note: The values in the brackets are the percentage of variation.

Table 8. The observed streamflow and simulated streamflow under different scenarios.

\begin{tabular}{ccccccccc}
\hline \multirow{2}{*}{ Scenarios } & \multirow{2}{*}{ Climate } & \multirow{2}{*}{ Land Use } & \multicolumn{2}{c}{ Streamflow $(\mathbf{m m} /$ Year) } & \multicolumn{2}{c}{ Observed Change } & \multicolumn{2}{c}{ Simulated Change } \\
\cline { 4 - 9 } & & Observed & Simulated & mm/Year & $\%$ & mm/Year & $\%$ \\
\hline S0 & $1970-1985$ & 1986 & 34.83 & 35.09 & - & - & - & -2.15 \\
\hline S1 & $1986-2000$ & 1986 & - & 32.94 & - & - & -6.13 \\
S2 & $2001-2014$ & 1986 & - & 36.78 & - & - & 1.69 & 4.82 \\
\hline S3 & $1970-1985$ & 1995 & - & 34.86 & - & - & -0.23 & -0.66 \\
S4 & $1970-1985$ & 2010 & - & 34.41 & - & - & -0.68 & -1.94 \\
\hline S5 & $1986-2000$ & 1995 & 25.90 & 32.61 & -2.48 & -25.63 & -2.45 & -7.07 \\
S6 & $2001-2014$ & 2010 & 30.79 & 35.93 & -0.84 & -11.60 & 0.84 & 2.39 \\
\hline
\end{tabular}

\subsection{The Impacts of Land Use Change on the Value of Hydrological Components}

The mean annual hydrological components of surface flow, lateral flow, baseflow and evapotranspiration under different land use scenarios are listed in the Table 9. Compared with S0, the increments in mean annual surface flow are of $0.154 \mathrm{~mm} /$ year and $0.363 \mathrm{~mm} /$ year under $\mathrm{S} 1$ and S2, respectively. The mean annual lateral flow decreased from $1.365 \mathrm{~mm} /$ year under S0 to $1.353 \mathrm{~mm}$ /year under S2 (a decrease of $0.88 \%$ ). Meanwhile, the mean annual baseflow decreased from $38.17 \mathrm{~mm}$ /year under S0 to $36.83 \mathrm{~mm} /$ year under S2 (a decrease of 3.51\%). Mean annual evapotranspiration increased from $246.825 \mathrm{~mm}$ /year under S0 to $267.334 \mathrm{~mm} /$ year under S2.

The forest land is identified as an "other" land use type when generating HRUS, because the forest land is scattered under S0 and S1 in the Hailiutu River basin. Therefore, the contribution of forest land to hydrological processes under S0 and S1 can be ignored. The water yield is mainly controlled by shrub and grass land and sandy land. It is worth mentioning that although the area of urban land accounts for small proportion of the entire basin, it contributes a large proportion of surface flow.

Under the impact of land use change, the simulated mean annual streamflow values during periods $\mathrm{C} 1$ and C2 are $34.86 \mathrm{~mm} /$ year and $34.41 \mathrm{~mm} /$ year, respectively (Table 8). Compared with the period 1970-1985, the variation in simulated mean annual streamflow during the two periods is of $-0.23 \mathrm{~mm} /$ year and $-0.68 \mathrm{~mm} /$ year, respectively. Considering the effect of land use change, the mean annual streamflow decreased by $0.66 \%$ and $1.94 \%$ during periods $C 1$ and $C 2$, respectively. 
Table 9. The contribution of different land use types to the value of hydrological components under different land use scenarios ( $\mathrm{mm} /$ year).

\begin{tabular}{|c|c|c|c|c|c|c|c|}
\hline Scenarios & & $\begin{array}{l}\text { Agricultural } \\
\text { Land }\end{array}$ & $\begin{array}{l}\text { Forest } \\
\text { Land }\end{array}$ & $\begin{array}{l}\text { Shrub and } \\
\text { Grass Land }\end{array}$ & $\begin{array}{l}\text { Urban } \\
\text { Land }\end{array}$ & $\begin{array}{l}\text { Sandy } \\
\text { Land }\end{array}$ & Total \\
\hline \multirow{4}{*}{ So } & Surface flow & 0.035 & - & 0.02 & 0.011 & 0.000 & 0.066 \\
\hline & Lateral flow & 0.184 & - & 0.606 & 0.002 & 0.573 & 1.365 \\
\hline & Baseflow & 1.778 & - & 19.433 & 0.005 & 16.955 & 38.171 \\
\hline & Evapotranspiration & 21.913 & - & 122.558 & 0.042 & 102.312 & 246.825 \\
\hline \multirow{4}{*}{ S3 } & Surface flow & 0.04 & - & 0.03 & 0.15 & 0.000 & 0.22 \\
\hline & Lateral flow & 0.192 & - & 0.659 & 0.002 & 0.508 & 1.361 \\
\hline & Baseflow & 1.863 & - & 20.397 & 0.025 & 15.283 & 37.568 \\
\hline & Evapotranspiration & 23.688 & - & 132.637 & 0.712 & 90.945 & 247.982 \\
\hline \multirow{4}{*}{$\mathrm{S} 4$} & Surface flow & 0.039 & 0.001 & 0.121 & 0.268 & 0.000 & 0.429 \\
\hline & Lateral flow & 0.171 & 0.023 & 0.879 & 0.003 & 0.277 & 1.353 \\
\hline & Baseflow & 1.688 & 0.799 & 26.522 & 0.129 & 7.693 & 36.831 \\
\hline & Evapotranspiration & 21.596 & 5.982 & 172.306 & 1.519 & 45.931 & 247.334 \\
\hline
\end{tabular}

\subsection{Combined Impacts of Climate Variability and Land Use Change on Streamflow}

The simulated streamflow and observed streamflow under combined scenarios (S5 and S6) are listed in the Table 8 . Under the combined impact of climate variability and land use change, the simulated mean annual streamflow values during periods $C 1$ and $C 2$ are $32.61 \mathrm{~mm}$ /year and $35.93 \mathrm{~mm} /$ year, respectively. The simulated mean annual stream flow decreased by $2.45 \mathrm{~mm} /$ year $(7.07 \%)$ during the period $\mathrm{C} 1$ and the contribution of these variations to the decrease in observed streamflow was $27.8 \%$. For period C2, the combined climate variability and land use change induced an increment of $0.84 \mathrm{~mm} /$ year $(2.39 \%)$ in the annual streamflow.

\subsection{Discussion}

In this study, observed precipitation data from 1970 to 2014 were applied to drive SWAT model. The CMADS was introduced to enhance the spatial expressiveness of precipitation data in the Hailiutu River basin during the period 2008-2014. To evaluate the performance of CMADS in the study area, the spatially averaged precipitation of CMADS is compared with observed data as shown in Figure 9. Based on the linear-regression analysis, it is shown that the precipitation from CMADS has a high correlation with the observed data, with a coefficient of determination value of 0.81 (Figure 9a). It can be seen from Figure $9 b$ that the precipitation duration curves obtained from CMADS and observed data are quite close to each other, especially for daily areal precipitation greater than $15 \mathrm{~mm}$. For daily areal precipitation of less than $15 \mathrm{~mm}$, the duration curve from CMADS is slightly lower than that of the observed data.

In order to further display the role of CMADS in the study area, three precipitation datasets, i.e., of observed precipitation (OBS), CMADS precipitation, and a combination of both (OBS+CMADS), were compared in the temporal and spatial scale. Figure 10 shows the comparison of areal precipitation of the whole basin obtained using different precipitation datasets. It was found that CMADS could better reflect the precipitation variation in the monthly scale. As mentioned earlier, CMADS trends to underestimate the precipitation when its value is less than $15 \mathrm{~mm}$. This would result in CMADS providing a lower precipitation value than OBS in the rainy season (May-September). For the other seasons, the areal precipitation obtained by CMADS was significantly lower than observed. In November 2011 in particular, the observed value was $58.2 \mathrm{~mm}$ while the value from CMADS was only $10.9 \mathrm{~mm}$. As shown in the Figure 1, only four rain gauges can participate to calculate areal precipitation in the study area. It is difficult to reproduce the actual areal precipitation as there is lack of adequate rain gauges. In the northwest of the study area in particular there is only one rain gauge which is located in the outside of the basin. It can be seen that introducing CMADS better reflects the spatial distribution of precipitation than OBS (Figure 11). Therefore, combined observed precipitation and precipitation of CMADS better reflected the temporal and spatial variation of the study area. 

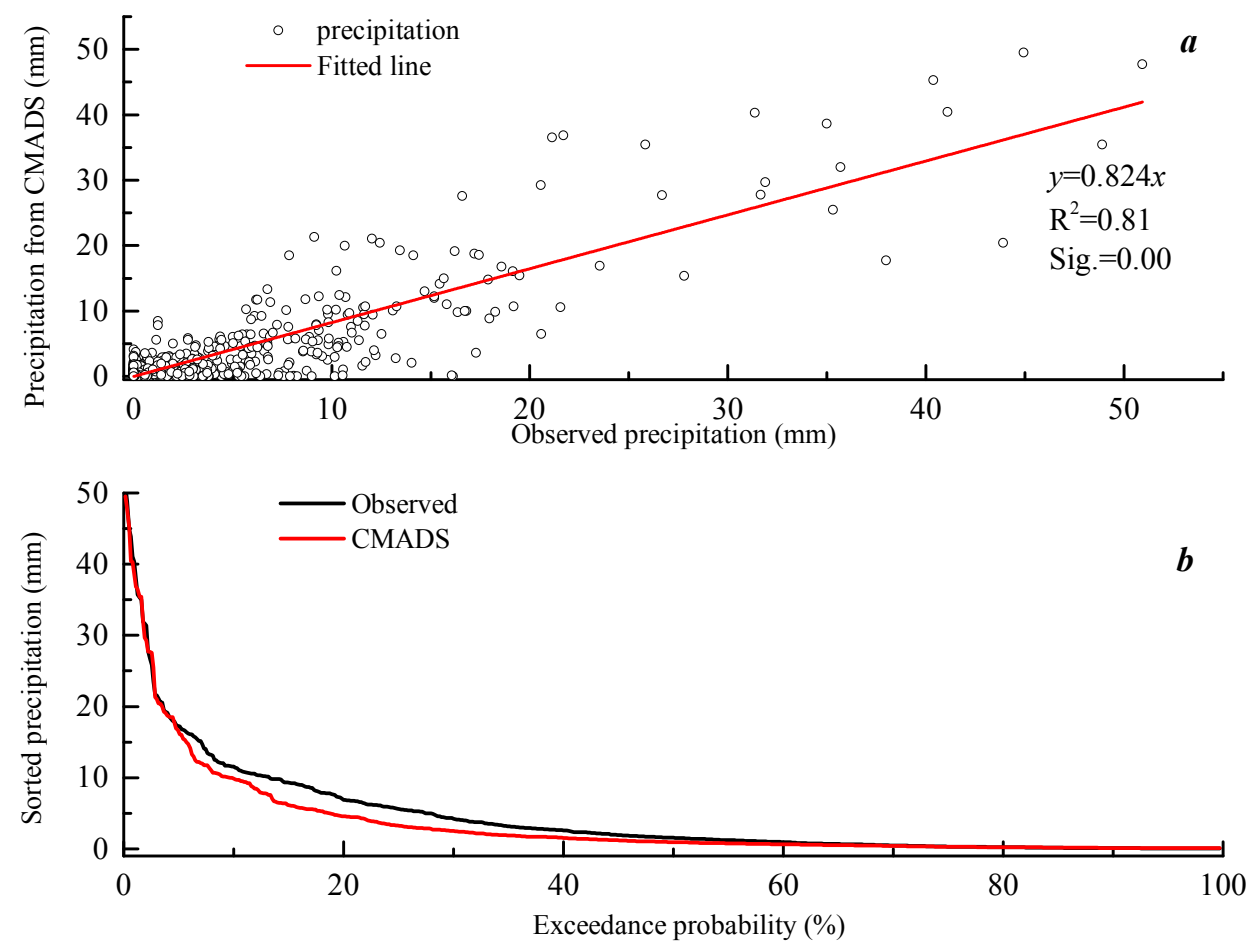

Figure 9. The evaluation of precipitation from CMADS. (a) A scattered plot of observed precipitation and CMADS precipitation; (b) the duration curve of observed precipitation and CMADS precipitation.

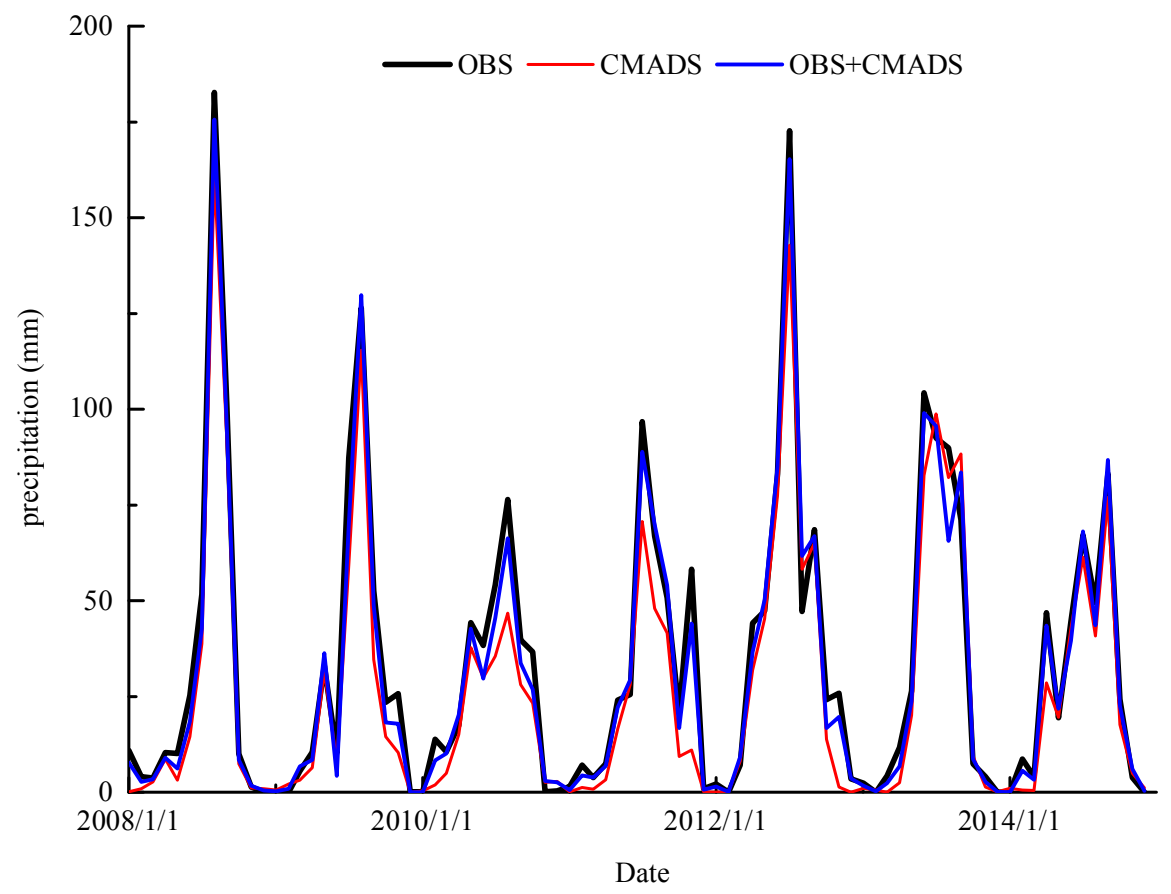

Figure 10. The comparison of monthly precipitation obtained by different precipitation datasets. 

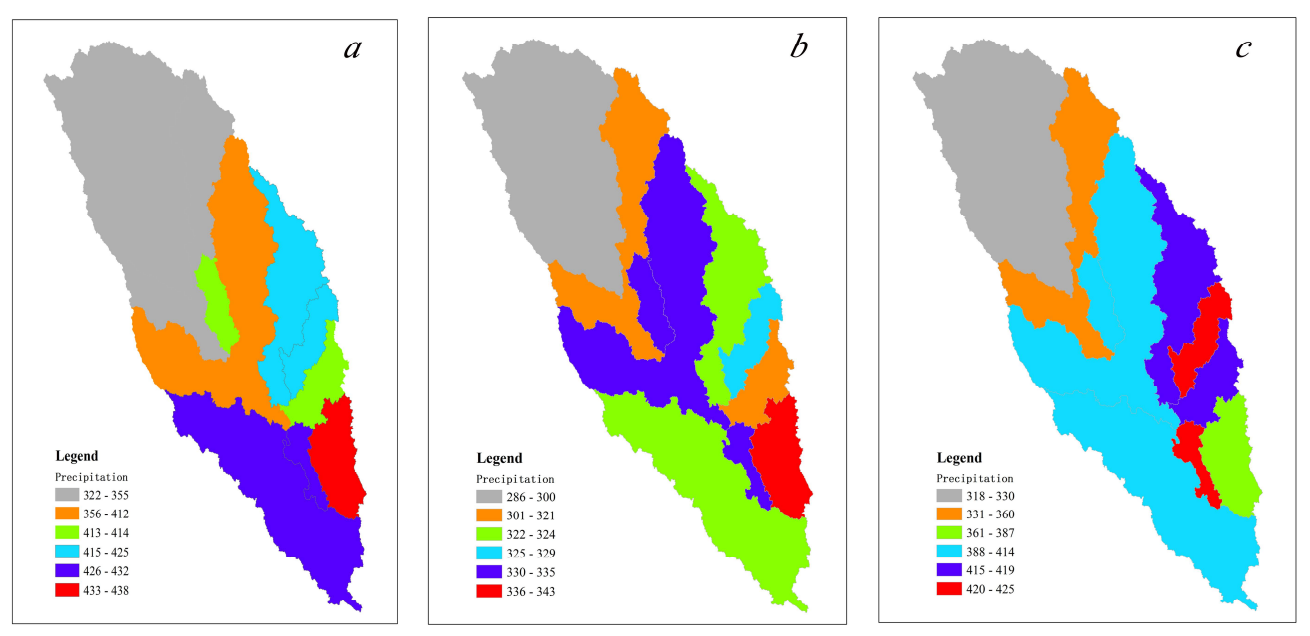

Figure 11. The spatial distribution of areal precipitation obtained by (a) OBS; (b) CMADS; and (c) OBS+CMADS.

The SWAT model was calibrated by observed precipitation (OBS) during the period 2008-2011 and values of calibrated parameters are listed in the Table 10. Then, the calibrated SWAT model was applied to evaluate the performance of CMADS and combination of both datasets (OBS+CMADS). Figure 12 shows that the criterion value ranges for the simulated streamflow of SWAT model with different driving data during the calibration and validation periods. For NSE values, OBS+CMADS generates the highest NSE with an average of 0.72 (calibration period) and 0.42 (validation period). The variation of the NSE value of OBS+CMADS is also less than for the other precipitation datasets. During the validation period, the CMADS has a lightly higher NSE than OBS, with an average of 0.12 , while the OBS mean is 0.10 . For the $\mathrm{R}^{2}$ values, OBS+CMADS and OBS have similar performance during the calibration period, while OBS+CMADS has a higher $\mathrm{R}^{2}(0.68)$ than OBS $(0.63)$ during the validation period. For the PBIAS values, during the calibration and validation periods, OBS and OBS+CMADS overestimate the streamflow, while the CMADS underestimates the streamflow. The simulation results from OBS+CMADS are relatively close to those of the observed data. To summarize, among all the precipitation data inputs for the simulation, the SWAT model with OBS+CMADS datasets was found to be able to give the best simulation results. Meanwhile, the performance of the SWAT model using OBS and OBS+CMADS was found to be better than only using CMADS data.

Table 10. The initial and calibrated parameters selected for the SWAT model during the period 2008-2011.

\begin{tabular}{lccc}
\hline Parameter & Initial Range & Calibrated Range & Best Value \\
\hline v_alpha_bf_u & 0.3 to 0.8 & 0.584 to 0.652 & 0.619 \\
v_gw_delay_u & 1 to 10 & 1.525 to 2.088 & 1.651 \\
v_alpha_bf_m & 0.005 to 0.1 & 0.032 to 0.053 & 0.041 \\
v_gw_delay_m & 30 to 350 & 212 to 259 & 245 \\
v_alpha_bf_1 & 0.001 to 0.05 & 0.023 to 0.032 & 0.027 \\
v_gw_delay_l & 250 to 500 & 405 to 500 & 492 \\
v_rchdp_mld & 0.92 to 1 & 0.988 to 0.992 & 0.989 \\
v_rchrg_ld & 0.6 to 0.95 & 0.915 to 0.956 & 0.937 \\
v_rchrg_d & 0.1 to 0.4 & 0.146 to 0.310 & 0.212 \\
v_gw_revap & 0.02 to 0.2 & 0.108 to 0.131 & 0.109 \\
r_CN2 & -0.5 to 0.5 & -0.237 to -0.191 & -0.211 \\
v_esco & 0.1 to 0.8 & 0.530 to 0.691 & 0.589 \\
a_awc & -0.04 to 0.1 & -0.024 to -0.016 & -0.022 \\
r_sol_k & -0.9 to 0.1 & -0.876 to -0.739 & -0.744 \\
\hline
\end{tabular}



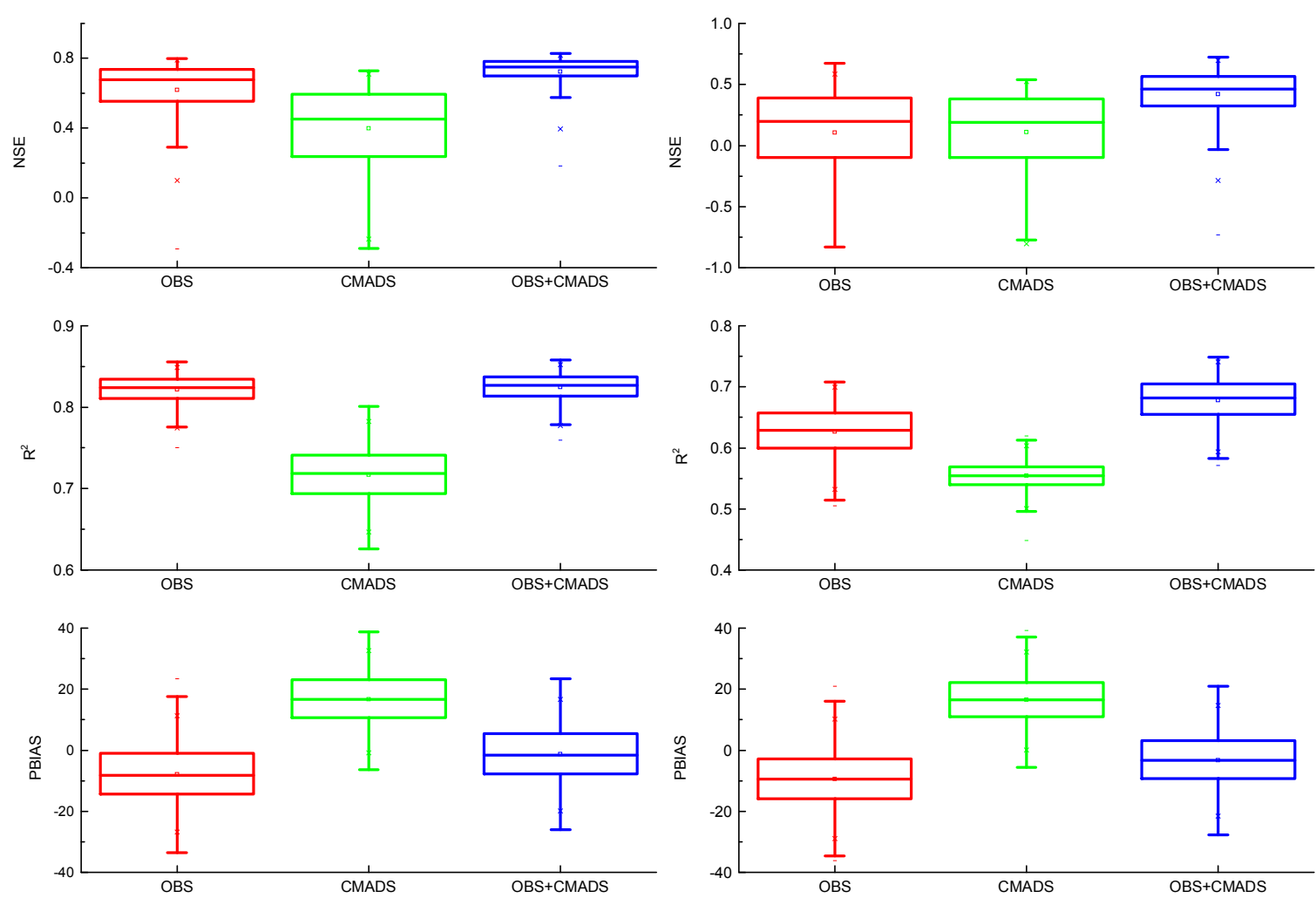

Figure 12. The box plots for the criteria of NSE (top), $R^{2}$ (medium) and PBIAS (bottom) during calibration period (left) and validation period (right). The square symbol and middle line in the box represent the mean value and median value, respectively. Each box ranges from the lower (25th) to upper quartile (75th). PBIAS: percent bias.

Figure 13 shows that the monthly streamflow simulated by using different precipitation datasets as inputs. Based on the Figure 13, OBS+CMADS outperforms the other precipitation datasets. For CMADS, although the CMADS trends to underestimate the precipitation, the streamflow simulated by CMADS is relatively close to observed streamflow. During the period 2011 to 2012, the simulated streamflow was significantly lower than the observed streamflow. This phenomenon could be explained by lower precipitation than OBS. Table 11 lists the $\mathrm{p}$-factor, $\mathrm{r}$-factor, and criterion value of best simulated streamflow for different precipitation input datasets. It was found that OBS+CMADS had the highest $\mathrm{p}$-factor value in both the calibration and validation periods. That means the streamflow simulated with OBS+CMADS could include more observation data than OBS and CMADS. During the validation period, CMADS has the lowest $r$-factor value and that means the streamflow simulated with CMADS more closely represents the observed streamflow than OBS and OBS+CMADS. For calibration period, OBS and OBS+CMADS have similar performance and OBS+CMADS outperforms than OBS. During the validation period, compared with OBS, the NSE value of OBS+CMADS was significantly improved (from 0.45 to 0.55 ). 
Table 11. The criterion value for the simulated streamflow of SWAT model with different driving data during the calibration and validation periods.

\begin{tabular}{ccccccc}
\hline \multirow{2}{*}{ Criterion } & \multicolumn{3}{c}{ Calibration Period } & \multicolumn{3}{c}{ Validation Period } \\
\cline { 2 - 7 } & OBS & CMADS & OBS+CMADS & OBS & CMADS & OBS+CMADS \\
\hline p-factor & 0.9 & 0.75 & 0.92 & 0.86 & 0.58 & 0.89 \\
r-factor & 0.87 & 0.51 & 0.94 & 1.43 & 1.14 & 1.34 \\
NSE & 0.80 & 0.73 & 0.83 & 0.45 & 0.46 & 0.55 \\
R $^{2}$ & 0.83 & 0.74 & 0.83 & 0.63 & 0.50 & 0.65 \\
PBIAS & 1.02 & 2.66 & -1.72 & -0.24 & 2.88 & -2.78 \\
\hline
\end{tabular}
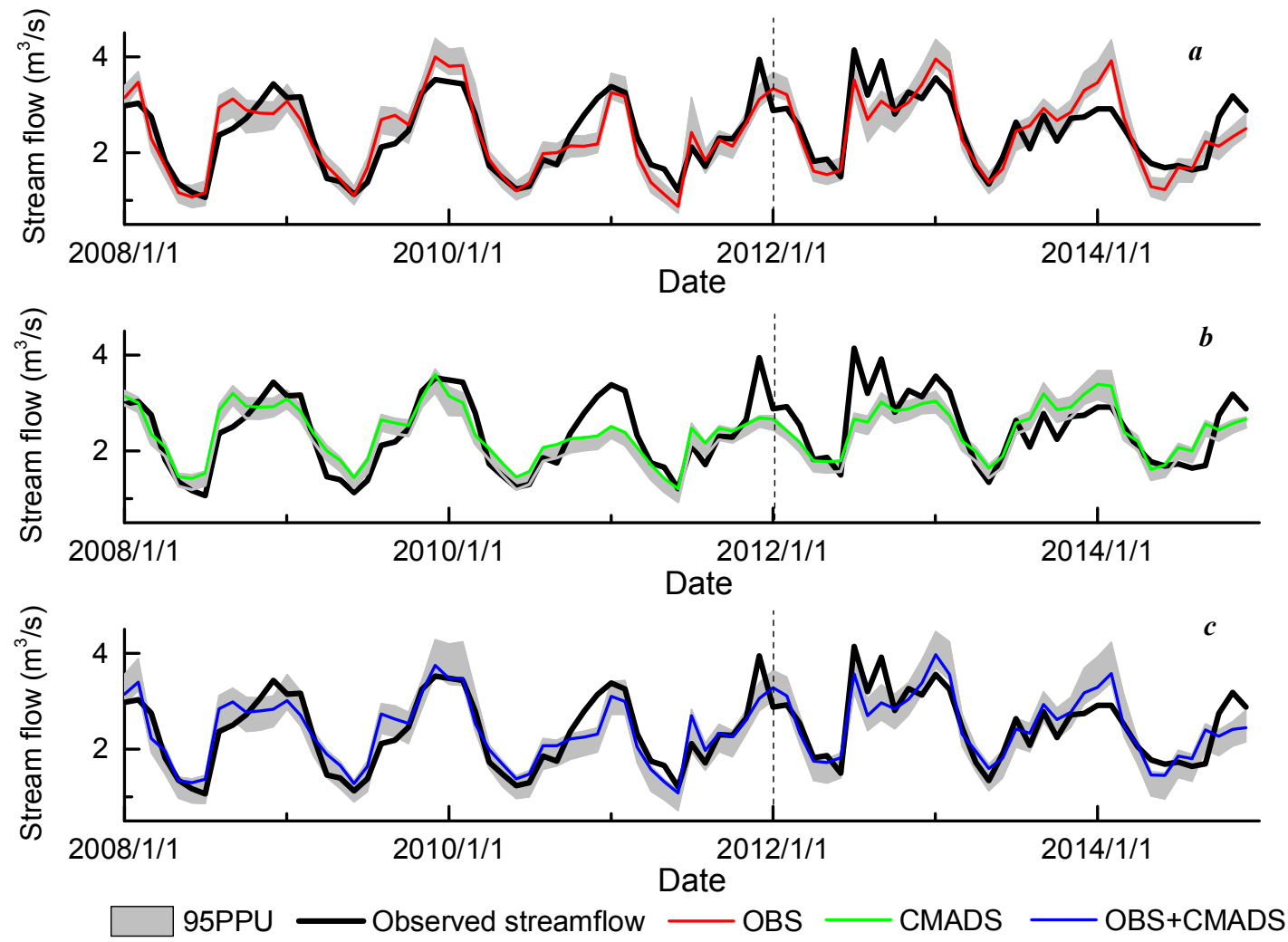

Figure 13. Simulation results of SWAT with (a) OBS; (b) CMADS; (c) OBS+CMADS in the Hailiutu River basin during the period 2008-2014.

To set up a hydrological model, for example the SWAT model, we usually use the measured precipitation data from rainfall gauge in the past. In some basins, there are more rain gauges $[13,69,70]$. For example, the Huangfuchuan basin is located near the Hailiutu River basin and covers an area of $3246 \mathrm{~km}^{2}$. This basin has a similar area to the Hailiutu River basin $\left(2473 \mathrm{Km}^{2}\right)$ and it has 12 rain gauges [13]. However, the Hailiutu River basin only has four rain gauges, of which only three rainfall stations are located in the watershed. Now, CMADS is available for the SWAT model users. It is free and very convenient to use. From the above results, it can be found that introducing the precipitation from CMADS can improve the simulation accuracy. This improvement can be attributed to introducing the CMADS to better reflect the precipitation spatial distribution. Thus, CMADS will be a very useful data source for hydrological modeling in China in the future.

In this study, as mentioned earlier, the whole study period was divided into three sub-periods. The calibrated model was expected to reflect the real hydrological process of the first sub-period. Nevertheless, there were some uncertain factors, e.g., the coarse spatial resolution of precipitation and the deficiency of model that affected the accuracy of the simulation. Those factors led to a difference between modeled and measured streamflow. However, streamflow/baseflow comparisons were made 
between different scenarios. Comparisons were not made with the measured streamflow/baseflow. The difference in the results could be attributed to the applied scenario changes only. Hessel et al. [71] also stated that all scenarios for one watershed are subjected to the same uncertain factors.

Based on the results of scenarios, the impact of climate variability and land use change on hydrological components can be compared. It is also observed that the impact of climate variability on the variation of streamflow is more profound compared to land use change. Compared with $\mathrm{S} 0$, in addition to land use change, the mean annual precipitation during $\mathrm{C} 1$ decreased. The variation of land use change and precipitation induced a decrease of $2.45 \mathrm{~mm} /$ year in the mean annual streamflow during the period C1 (Table 8). An increment of $0.84 \mathrm{~mm} /$ year in mean annual streamflow was observed during period C2 because of the effect of the climate variability. During the periods of C1 and $\mathrm{C} 2$, the observed mean annual streamflow recorded relatively lesser flows than the simulated streamflow, and the observed streamflow decreased while the simulated streamflow increased in the period of C2. After the 1980s, many diversion dams were constructed in the Hailiutu River basin for local water supply [72]. In recent years, water demand has increased rapidly with the development of energy and agriculture. This has resulted in more exploitation of groundwater resources and streamflow reduction $[40,73]$. Therefore, the impact of these factors on streamflow reduction in Hailiutu River basin should be considered in the hydrological modeling in the future.

\section{Conclusions}

In this paper, the statistics analysis methods and hydrological modeling were applied to assess the impacts of climate variability and land use change on the hydrological components in the Hailiutu River basin of the Chinese Erdos Plateau, and the combined impacts of climate and land use change on streamflow reduction were also analyzed. The results are listed as follows:

The CMADS was introduced to improve the spatial expressiveness of precipitation data in the study area over the period 2008-2014. There is a good correlation between CMADS and the observed data during this period. The SWAT model was calibrated by observed data during the period 2008-2011. Compared with only using observed precipitation data, the NSE value increased from 0.80 to 0.83 when using combined data during 2008-2011 and increased from 0.45 to 0.55 when using combined data during 2012-2014. The $\mathrm{R}^{2}$ value increased from 0.63 to 0.65 when using combined data during 2012-2014. This proves that the performance of SWAT model when using combined observed and CMADS precipitation values was significantly improved. It suggests that combining the CMADS with traditional hydrological measurements might be very helpful for improving hydrological modeling.

The Mann-Kendall test of annual hydrometeorology series indicated that streamflow and wind speed showed a significantly downward trend during the period 1970-2014. A slight upward trend was detected for precipitation while a significantly upward trend was detected for temperature. From the analysis of the STARS test, the years 1986 and 2001 were detected as change points for annual streamflow. The years 1979 and 1998 were detected as change points for annual wind speed. The year 1999 was detected as a change point for all temperature series, and 2005 as the change point for annual maximum temperature series. Based on the change points of annual streamflow, the whole study period was divided into three sub-periods, i.e., 1970-1985, 1986-2000, and 2001-2014.

Compared with 1970-1985, the mean monthly streamflow during the period 1986-2000 decreased, especially in September and October. The streamflow increased during the period 2001-2014, with almost no variation compared with the period 1986-2000 from May to July. The precipitation during the period 1986-2000 substantially decreased as compared with the period 1970-1985. During the period 2001-2014, the precipitation rose to similar values as the period 1970-1985. From the comparison among monthly temperature in three periods, the annual maximum temperature showed an upward trend during January-June, and the annual minimum and average temperature presented upward trends in all the months. In the study area, the main variations of land use were increased area of shrub and grass land (from $51.10 \%$ of 1986 to $72.68 \%$ of 2010 ) and decreased area of sandy land (from $43.31 \%$ of 1986 to $19.48 \%$ of 2010). These variations can be explained by the 
implementation of the project of "Three North Forest Shelterbelts" and policy of "Closing Sandy Land and Forbidding Herding".

As compared to the period 1970-1985, the climate variability led to a significant decrease in streamflow during the period 1986-2000, and induced a moderate increase in streamflow during the period 2000-2014. The land use changes caused increases in surface runoff, evapotranspiration, and decreases in baseflow, lateral flow, and streamflow. These changes are mainly attributed to the increase of shrub and grass land area and a decrease of sandy land area. In general, the impacts of climate variability on the value of hydrological components were more profound than land use change in the Hailiutu River basin. Therefore, the importance of increasing adaptation to climate variability should be considered when planning and managing water resources.

Compared to the period 1970-1985, the observed mean annual streamflow decreased during the periods 1986-2000 and 2001-2014. During the period 1986-2000, the climate variability and land use change resulted in a decrease of mean annual streamflow by $6.13 \%$ and $0.66 \%$, respectively. The combined climate variability and land use change induced a decrease in mean annual streamflow by $7.07 \%$, and was responsible for $27.87 \%$ of the decrease in observed mean annual streamflow. For the period 2001-2014, land use change induced a 1.94\% decrease in mean annual streamflow. There was a positive impact of climate variability on the streamflow, with an increment of $4.82 \%$. Under the impact of combined climate variability and land use change, it was observed that mean annual streamflow increased by $2.39 \%$. The discrepancy between observed and simulated streamflow during the period 2001-2014 implies that the impact of other factors such as local water supply and exploitation of groundwater on the streamflow in Hailiutu River basin may not be ignored in hydrological modeling.

Author Contributions: Y.G. and D.Z. were primarily accountable for data collection and design and coordination of the study. G.S. were responsible for data analysis and writing of the paper. B.Y. and J.Z. were responsible for results presentation.

Funding: This research was funded by the National Natural Science Foundation of China (NSFC51579067 and NSFC51209064), the Qing Lan Project, and the Postgraduate Research \& Practice Innovation Program of Jiangsu Province (KYCX17_0416).

Acknowledgments: Great thanks to Victoria Adjei from Hohai University (China) for the editing of the English language and style of this manuscript. The authors also thank the anonymous reviewers for their very valuable comments.

Conflicts of Interest: The authors declare no conflict of interest.

\section{References}

1. Oki, T.; Kanae, S. Global hydrological cycles and world water resources. Science 2006, 313, $1068-1072$. [CrossRef] [PubMed]

2. Stocker, T. Climate Change 2013: The Physical Science Basis: Working Group I Contribution to the Fifth Assessment Report of the Intergovernmental Panel on Climate Change; Cambridge University Press: Cambridge, UK, 2014.

3. Chen, Y.; Xu, Y.; Yin, Y. Impacts of land use change scenarios on storm-runoff generation in Xitiaoxi basin, China. Quat. Int. 2009, 208, 121-128. [CrossRef]

4. Sajikumar, N.; Remya, R.S. Impact of land cover and land use change on runoff characteristics. J. Environ. Manag. 2015, 161, 460-468. [CrossRef] [PubMed]

5. Tadesse, W.; Whitaker, S.; Crosson, W.; Wilson, C. Assessing the Impact of Land-Use Land-Cover Change on Stream Water and Sediment Yields at a Watershed Level Using SWAT. Open J. Mod. Hydrol. 2015, 5, 68. [CrossRef]

6. Woldesenbet, T.A.; Elagib, N.A.; Ribbe, L.; Heinrich, J. Hydrological responses to land use/cover changes in the source region of the Upper Blue Nile Basin, Ethiopia. Sci. Total Environ. 2017, 575, 724-741. [CrossRef] [PubMed]

7. Li, Z.; Liu, W.; Zhang, X.; Zheng, F. Impacts of land use change and climate variability on hydrology in an agricultural catchment on the Loess Plateau of China. J. Hydrol. 2009, 377, 35-42. [CrossRef]

8. Liu, Z.; Yao, Z.; Huang, H.; Wu, S.; Liu, G. Land Use and Climate Changes and Their Impacts on Runoff in the Yarlung Zangbo River Basin, China. Land Degrad. Dev. 2014, 25, 203-215. [CrossRef] 
9. López-Moreno, J.I.; Vicente-Serrano, S.M.; Moran-Tejeda, E.; Zabalza, J.; Lorenzo-Lacruz, J.; García-Ruiz, J.M. Impact of climate evolution and land use changes on water yield in the Ebro basin. Hydrol. Earth Syst. Sci. 2011, 15, 311-322. [CrossRef]

10. Li, L.J.; Zhang, L.; Wang, H.; Wang, J.; Yang, J.W.; Jiang, D.J.; Li, J.Y.; Qin, D.Y. Assessing the impact of climate variability and human activities on streamflow from the Wuding River basin in China. Hydrol. Process. 2007, 21, 3485-3491. [CrossRef]

11. Du, J.; Rui, H.; Zuo, T.; Li, Q.; Zheng, D.; Chen, A.; Xu, Y.; Xu, C.-Y. Hydrological Simulation by SWAT Model with Fixed and Varied Parameterization Approaches Under Land Use Change. Water Resour. Manag. 2013, 27, 2823-2838. [CrossRef]

12. Brown, A.E.; Zhang, L.; McMahon, T.A.; Western, A.W.; Vertessy, R.A. A review of paired catchment studies for determining changes in water yield resulting from alterations in vegetation. J. Hydrol. 2005, 310, $28-61$. [CrossRef]

13. Zuo, D.; Xu, Z.; Yao, W.; Jin, S.; Xiao, P.; Ran, D. Assessing the effects of changes in land use and climate on runoff and sediment yields from a watershed in the Loess Plateau of China. Sci. Total Environ. 2016, 544, 238-250. [CrossRef] [PubMed]

14. Park, J.-Y.; Park, M.-J.; Joh, H.-K.; Shin, H.-J.; Kwon, H.-J.; Srinivasan, R.; Kim, S.-J. Assessment of MIROC3.2 HiRes Climate and CLUE-s Land Use Change Impacts on Watershed Hydrology Using SWAT. Trans. ASABE 2011, 54, 1713-1724. [CrossRef]

15. Khoi, D.N.; Suetsugi, T. The responses of hydrological processes and sediment yield to land-use and climate change in the Be River Catchment, Vietnam. Hydrol. Process. 2014, 28, 640-652. [CrossRef]

16. Tu, J. Combined impact of climate and land use changes on streamflow and water quality in eastern Massachusetts, USA. J. Hydrol. 2009, 379, 268-283. [CrossRef]

17. Ashagre, B.B. SWAT to Identify Watershed Management Options: Anjeni Watershed, Blue Nile Basin, Ethiopia. Master's Thesis, Cornell University, New York, NY, USA, 2009.

18. Baker, T.J.; Miller, S.N. Using the Soil and Water Assessment Tool (SWAT) to assess land use impact on water resources in an East African watershed. J. Hydrol. 2013, 486, 100-111. [CrossRef]

19. Bieger, K.; Hörmann, G.; Fohrer, N. The impact of land use change in the Xiangxi Catchment (China) on water balance and sediment transport. Reg. Environ. Chang. 2015, 15, 485-498. [CrossRef]

20. Rahman, K.; da Silva, A.G.; Tejeda, E.M.; Gobiet, A.; Beniston, M.; Lehmann, A. An independent and combined effect analysis of land use and climate change in the upper Rhone River watershed, Switzerland. Appl. Geogr. 2015, 63, 264-272. [CrossRef]

21. Yin, Z.; Feng, Q.; Yang, L.; Wen, X.; Si, J.; Zou, S. Long Term Quantification of Climate and Land Cover Change Impacts on Streamflow in an Alpine River Catchment, Northwestern China. Sustainability 2017, 9 , 1278. [CrossRef]

22. Kim, J.; Choi, J.; Choi, C.; Park, S. Impacts of changes in climate and land use/land cover under IPCC RCP scenarios on streamflow in the Hoeya River Basin, Korea. Sci. Total Environ. 2013, 452-453, 181-195. [CrossRef] [PubMed]

23. Zhang, A.; Zhang, C.; Fu, G.; Wang, B.; Bao, Z.; Zheng, H. Assessments of Impacts of Climate Change and Human Activities on Runoff with SWAT for the Huifa River Basin, Northeast China. Water Resour. Manag. 2012, 26, 2199-2217. [CrossRef]

24. Chen, Z.; Chen, Y.; Li, B. Quantifying the effects of climate variability and human activities on runoff for Kaidu River Basin in arid region of northwest China. Theor. Appl. Climatol. 2013, 111, 537-545. [CrossRef]

25. Miao, C.; Ashouri, H.; Hsu, K.-L.; Sorooshian, S.; Duan, Q. Evaluation of the PERSIANN-CDR Daily Rainfall Estimates in Capturing the Behavior of Extreme Precipitation Events over China. J. Hydrometeorol. 2015, 16, 1387-1396. [CrossRef]

26. Stisen, S.; Sandholt, I. Evaluation of remote-sensing-based rainfall products through predictive capability in hydrological runoff modelling. Hydrol. Process. 2010, 24, 879-891. [CrossRef]

27. Su, F.; Hong, Y.; Lettenmaier, D.P. Evaluation of TRMM Multisatellite Precipitation Analysis (TMPA) and Its Utility in Hydrologic Prediction in the La Plata Basin. J. Hydrometeorol. 2008, 9, 622-640. [CrossRef]

28. Liu, J.; Shanguan, D.; Liu, S.; Ding, Y. Evaluation and Hydrological Simulation of CMADS and CFSR Reanalysis Datasets in the Qinghai-Tibet Plateau. Water 2018, 10, 513. [CrossRef]

29. Vu, T.T.; Li, L.; Jun, K.S. Evaluation of Multi-Satellite Precipitation Products for Streamflow Simulations: A Case Study for the Han River Basin in the Korean Peninsula, East Asia. Water 2018, 10, 642. [CrossRef] 
30. Zhao, F.; Wu, Y.; Qiu, L.; Sun, Y.; Sun, L.; Li, Q.; Niu, J.; Wang, G. Parameter Uncertainty Analysis of the SWAT Model in a Mountain-Loess Transitional Watershed on the Chinese Loess Plateau. Water 2018, 10, 690. [CrossRef]

31. Cao, Y.; Zhang, J.; Yang, M.; Lei, X.; Guo, B.; Yang, L.; Zeng, Z.; Qu, J. Application of SWAT Model with CMADS Data to Estimate Hydrological Elements and Parameter Uncertainty Based on SUFI-2 Algorithm in the Lijiang River Basin, China. Water 2018, 10, 742. [CrossRef]

32. Zhou, Y.; Wenninger, J.; Yang, Z.; Yin, L.; Huang, J.; Hou, L.; Wang, X.; Zhang, D.; Uhlenbrook, S. Groundwater-surface water interactions, vegetation dependencies and implications for water resources management in the semi-arid Hailiutu River catchment, China-A synthesis. Hydrol. Earth Syst. Sci. 2013, 17, 2435-2447. [CrossRef]

33. Gao, T.; Wang, H. Trends in precipitation extremes over the Yellow River basin in North China: Changing properties and causes. Hydrol. Process. 2017, 31, 2412-2428. [CrossRef]

34. Jiang, P.; Yu, Z.; Gautam, M.R.; Acharya, K. The Spatiotemporal Characteristics of Extreme Precipitation Events in the Western United States. Water Resour. Manag. 2016, 30, 4807-4821. [CrossRef]

35. Li, H.; Zhang, Q.; Singh, V.P.; Shi, P.; Sun, P. Hydrological effects of cropland and climatic changes in arid and semi-arid river basins: A case study from the Yellow River basin, China. J. Hydrol. 2017, 549, 547-557. [CrossRef]

36. Li, B.; Li, C.; Liu, J.; Zhang, Q.; Duan, L. Decreased Streamflow in the Yellow River Basin, China: Climate Change or Human-Induced? Water 2017, 9, 116. [CrossRef]

37. Wang, S.; Yan, Y.; Yan, M.; Zhao, X. Quantitative estimation of the impact of precipitation and human activities on runoff change of the Huangfuchuan River Basin. J. Geogr. Sci. 2012, 22, 906-918. [CrossRef]

38. Hou, L.; Zhou, Y.; Bao, H.; Wenninger, J. Simulation of maize (Zea mays L.) water use with the HYDRUS-1D model in the semi-arid Hailiutu River catchment, Northwest China. Hydrol. Sci. J. 2017, 62, 93-103. [CrossRef]

39. Yang, Z.; Zhou, Y.; Wenninger, J.; Uhlenbrook, S. A multi-method approach to quantify groundwater/surface water-interactions in the semi-arid Hailiutu River basin, northwest China. Hydrogeol. J. 2014, 22, 527-541. [CrossRef]

40. Yang, Z.; Zhou, Y.; Wenninger, J.; Uhlenbrook, S.; Wang, X.; Wan, L. Groundwater and surface-water interactions and impacts of human activities in the Hailiutu catchment, northwest China. Hydrogeol. J. 2017, 25, 1341-1355. [CrossRef]

41. Xu, Z.X.; Takeuchi, K.; Ishidaira, H.; Zhang, X.W. Sustainability Analysis for Yellow River Water Resources Using the System Dynamics Approach. Water Resour. Manag. 2002, 16, 239-261. [CrossRef]

42. Huo, Z.; Feng, S.; Kang, S.; Li, W.; Chen, S. Effect of climate changes and water-related human activities on annual stream flows of the Shiyang river basin in arid north-west China. Hydrol. Process. 2008, 22, 3155-3167. [CrossRef]

43. Zhang, X.; Zhang, L.; Zhao, J.; Rustomji, P.; Hairsine, P. Responses of streamflow to changes in climate and land use/cover in the Loess Plateau, China. Water Resour. Res. 2008, 44. [CrossRef]

44. Zhou, Y.; Yang, Z.; Zhang, D.; Jin, X.; Zhang, J. Inter-catchment comparison of flow regime between the Hailiutu and Huangfuchuan rivers in the semi-arid Erdos Plateau, Northwest China. Hydrol. Sci. J. 2015, 60, 688-705. [CrossRef]

45. Chen, Y.; Guan, Y.; Shao, G.; Zhang, D. Investigating Trends in Streamflow and Precipitation in Huangfuchuan Basin with Wavelet Analysis and the Mann-Kendall Test. Water 2016, 8, 77. [CrossRef]

46. Huang, J.; Hou, G.; Li, H.; Yin, L.; Lu, H.; Zhang, J.; Dong, J. Estimating subdaily evapotranspiration rates using the corrected diurnal water-table fluctuations in a shallow groundwater table area. In Proceedings of the 2011 International Symposium on Water Resource and Environmental Protection, Xi'an, China, 20-22 May 2011; Volume 4, pp. 3093-3099.

47. Wang, X.-S.; Zhou, Y. Shift of annual water balance in the Budyko space for a catchment with groundwater dependent evapotranspiration. Hydrol. Earth Syst. Sci. Discuss. 2015, 12, 11613-11650. [CrossRef]

48. Yin, L.; Zhou, Y.; Huang, J.; Wenninger, J.; Hou, G.; Zhang, E.; Wang, X.; Dong, J.; Zhang, J.; Uhlenbrook, S. Dynamics of willow tree (Salix matsudana) water use and its response to environmental factors in the semi-arid Hailiutu River catchment, Northwest China. Environ. Earth Sci. 2014, 71, 4997-5006. [CrossRef] 
49. Yang, Z.; Zhou, Y.; Wenninger, J.; Uhlenbrook, S.; Wan, L. Simulation of Groundwater-Surface Water Interactions under Different Land Use Scenarios in the Bulang Catchment, Northwest China. Water 2015, 7, 5959-5985. [CrossRef]

50. Meng, X.Y. China Meteorological Assimilation Driving Datasets for the SWAT Model, version 1.0.; Cold and Arid Regions Science Data Center at Lanzhou: Lanzhou, China, 2016. [CrossRef]

51. Meng, X.; Wang, H. Significance of the China Meteorological Assimilation Driving Datasets for the SWAT Model (CMADS) of East Asia. Water 2017, 9, 765. [CrossRef]

52. Meng, X.; Long, A.; Wu, Y.; Yin, G.; Wang, H.; Ji, X. Simulation and spatiotemporal pattern of air temperature and precipitation in Eastern Central Asia using RegCM. Sci. Rep. 2018, 8, 3639. [CrossRef] [PubMed]

53. Meng, X.; Wang, H.; Lei, X.; Cai, S.; Wu, H.; Ji, X.; Wang, J. Hydrological modeling in the Manas River Basin using soil and water assessment tool driven by CMADS. Teh. Vjesn. 2017, 24, 525-534.

54. Meng, X.; Wang, H.; Wu, Y.; Long, A.; Wang, J.; Shi, C.; Ji, X. Investigating spatiotemporal changes of the land-surface processes in Xinjiang using high-resolution CLM3. 5 and CLDAS: Soil temperature. Sci. Rep. 2017, 7, 13286. [CrossRef] [PubMed]

55. Meng, X.; Wang, H.; Cai, S.; Zhang, X.; Leng, G.; Lei, X.; Shi, C.; Liu, S.; Shang, Y. The China Meteorological Assimilation Driving Datasets for the SWAT Model (CMADS) Application in China: A Case Study in Heihe River Basin. Preprints 2017. [CrossRef]

56. Yue, S.; Wang, C. The Mann-Kendall Test Modified by Effective Sample Size to Detect Trend in Serially Correlated Hydrological Series. Water Resour. Manag. 2004, 18, 201-218. [CrossRef]

57. Sang, Y.-F.; Wang, Z.; Liu, C. Comparison of the MK test and EMD method for trend identification in hydrological time series. J. Hydrol. 2014, 510, 293-298. [CrossRef]

58. Belete, M.D. The impact of sedimentation and climate variability on the hydrological status of Lake Hawassa, South Ethiopia. Ph.D. Thesis, Universitäts- und Landesbibliothek Bonn, Bonn, Germany, 2013.

59. Rodionov, S.N. A sequential algorithm for testing climate regime shifts. Geophys. Res. Lett. 2004, 31 , L09204. [CrossRef]

60. Gong, X.; Liu, Z.; Gao, H.; Yang, H.; Wang, H. Regime Shifts in the Huanghe Freshwater Discharge During the Past Fifty Years. In Proceedings of the 2009 3rd International Conference on Bioinformatics and Biomedical Engineering, Beijing, China, 11-13 June 2009; pp. 1-3.

61. Neitsch, S.L.; Arnold, J.G.; Kiniry, J.R.; Williams, J.R. Soil and Water Assessment Tool Theoretical Documentation, version 2009; Texas Water Resources Institute: College Station, TX, USA, 2011.

62. Panagopoulos, Y.; Gassman, P.W.; Jha, M.K.; Kling, C.L.; Campbell, T.; Srinivasan, R.; White, M.; Arnold, J.G. A refined regional modeling approach for the Corn Belt-Experiences and recommendations for large-scale integrated modeling. J. Hydrol. 2015, 524, 348-366. [CrossRef]

63. Qi, J.; Li, S.; Jamieson, R.; Hebb, D.; Xing, Z.; Meng, F.-R. Modifying SWAT with an energy balance module to simulate snowmelt for maritime regions. Environ. Model. Softw. 2017, 93, 146-160. [CrossRef]

64. Shirmohammadi, A.; Chu, T.W. Evaluation of the swat model's hydrology component in the piedmont physiographic region of Maryland. Trans. ASAE 2004, 47, 1057-1073.

65. Amatya, D.M.; Jha, M.; Edwards, A.E.; Williams, T.M.; Hitchcock, D.R. SWAT-based streamflow and embayment modeling of karst-affected Chapel branch watershed, South Carolina. Trans. ASABE 2011, 54, 1311-1323. [CrossRef]

66. Cheng, L.; Xu, Z.X.; Luo, R. SWAT application in arid and semi-arid region: A case study in the Kuye River Basin. Geogr. Res. 2009, 28, 65-73.

67. Abbaspour, K.C.; Johnson, C.A.; van Genuchten, M.T. Estimating Uncertain Flow and Transport Parameters Using a Sequential Uncertainty Fitting Procedure. Vadose Zone J. 2004, 3, 1340. [CrossRef]

68. Moriasi, D.N.; Gitau, M.W.; Pai, N.; Daggupati, P. Hydrologic and water quality models: Performance measures and evaluation criteria. Trans ASABE 2015, 58, 1763-1785.

69. Zhang, S.; Fan, W.; Li, Y.; Yi, Y. The influence of changes in land use and landscape patterns on soil erosion in a watershed. Sci. Total Environ. 2017, 574, 34-45. [CrossRef] [PubMed]

70. Tian, Y.; Wang, S.; Bai, X.; Luo, G.; Xu, Y. Trade-offs among ecosystem services in a typical Karst watershed, SW China. Sci. Total Environ. 2016, 566-567, 1297-1308. [CrossRef] [PubMed]

71. Hessel, R.; Messing, I.; Liding, C.; Ritsema, C.; Stolte, J. Soil erosion simulations of land use scenarios for a small Loess Plateau catchment. CATENA 2003, 54, 289-302. [CrossRef] 
72. Yang, Z.; Zhou, Y.; Wenninger, J.; Uhlenbrook, S. The causes of flow regime shifts in the semi-arid Hailiutu River, Northwest China. Hydrol. Earth Syst. Sci. 2011, 8, 5999-6030. [CrossRef]

73. Yin, L.; Hu, G.; Huang, J.; Wen, D.; Dong, J.; Wang, X.; Li, H. Groundwater-recharge estimation in the Ordos Plateau, China: Comparison of methods. Hydrogeol. J. 2011, 19, 1563-1575. [CrossRef] 